\title{
Changes of potential catches for North-East Atlantic small pelagic fisheries under climate change scenarios
}

Jose A. Fernandes ${ }^{1,2}$, Thomas L. Frölicher ${ }^{3}$, Louise A. Rutterford ${ }^{4,5,6}$, Maite ErauskinExtramiana $^{1}$, William W.L. Cheung ${ }^{7}$

1. AZTI, Marine Research, Basque Research and Technology Alliance (BRTA), Herrera Kaia, Portualdea, z/g, Pasaia (Gipuzkoa), 20110, Spain

2. Plymouth Marine Laboratory, Prospect Place, The Hoe, Plymouth, U.K. PL13 DH

3. Environmental Physics, Institute of Biogeochemistry and Pollutant Dynamics, ETH Zürich, Switzerland.

4. Biosciences, College of Life and Environmental Sciences, University of Exeter, Stocker Road, Exeter, EX4 4QD, UK.

5. School of Biological Sciences, Life Sciences Building, University of Bristol, Bristol, BS8 1TQ, UK.

6. Centre for Environment Fisheries and Aquaculture Science (Cefas), Lowestoft Laboratory, Pakefield Road, Lowestoft, Suffolk, NR33 0HT, UK.

7. Nippon Foundation-Nereus Program, Institute for the Oceans and Fisheries, The University of British Columbia, Vancouver, BC, Canada V6 T 1Z4

Keywords: Climate change, Marine fisheries, Modelling, Projections, Uncertainty, Ecosystem Approach, Fisheries Management, Widely distributed species, Pelagic species 


\section{Abstract}

34 Small and intermediate-size pelagic fisheries are highly impacted by environmental variability and climate change. Their wide geographical distribution and high mobility makes them more likely to shift their distribution under climate change. Here, we explore the potential impact of different climate change scenarios on the four main commercial pelagic species in the NorthEast Atlantic (NEA): Atlantic mackerel (Scomber scombrus), European sprat (Sprattus sprattus), Atlantic herring (Clupea harengus) and blue whiting (Micromesistius poutassou). We used a process-based fisheries model (SS-DBEM), where all the target species were exploited at their maximum sustainable yield (MSY), to project future potential catches under a high and low future greenhouse gas scenario (RCP 2.6 and 8.5, respectively). Two ocean biogeochemical models (GDFL and MEDUSA) were used to force the environmental conditions. Mackerel and sprat are projected to have increases in a potential catch under both scenarios. Herring and blue whiting are projected to increase under the RCP2.6, but future projections under RCP8.5 show mixed responses with decreases or no changes forecasted. Overall, the potential catch is projected to increase in the northern area of the NEA but is projected to decrease in the southern area. These projected changes are mainly driven by changes in temperature and primary production. Shifts in the distribution of pelagic resources may destabilize existing international agreements on sharing of straddling resources as exemplified by the dispute in sharing of quota for Atlantic mackerel. Novel climate-ready policy approaches considering full species distribution are needed to complement current stock-based approaches. 


\section{Introduction}

The North Atlantic sustains some of the largest populations of commercially exploited fish stocks in the world (Trenkel et al., 2014). Four temperate-boreal pelagic species account for more than $65 \%$ of the total catches and $95 \%$ of pelagic species catch in the North-East Atlantic (NEA) (Merino et al., 2014, Trenkel et al., 2014): Atlantic herring (Clupea harengus), Atlantic mackerel (Scomber scombrus), European sprat (Sprattus sprattus) and blue whiting (Micromesistius poutassou). Atlantic mackerel (Scomber scombrus), European sprat (Sprattus sprattus), Atlantic herring (Clupea harengus) and blue whiting (Micromesistius poutassou). These species are widely distributed and subject to large annual migrations (Corten, 2002; Ruzzante et al., 2006; Huse et al., 2010). Fisheries catch statistics from International Council for the Exploration of the Sea (ICES) database (http://ices.dk/marine-data/datasetcollections/Pages/default.aspx) during the period 2006-2013 show that the eastern ICES areas in the North Atlantic tend to support higher catches of herring (Fig. 1) whereas western ICES areas in the NEA are more dependent on blue whiting. Mackerel catches are more concentrated on the mid-northern ICES areas while sprat catches concentrate in the Baltic Sea (ICES area III). Norway has the highest catches for blue whiting, herring and mackerel but its sprat catches are small. Denmark exploits more sprat and herring while catching a small proportion of the rest of the species. Harvesting countries of blue whiting, herring and mackerel are Norway, Russia, Iceland and Faroe Islands. Historic records show that the Netherlands had a blue whiting fishery in the past. Between 2014-2017, the top 5 exploiters countries for mackerel were also the United Kingdom, Norway, Iceland, Russia and Faeroe Islands, whereas the main sprat catches were from Denmark, Poland, Russia and Latvia. Despite other Bboreal/arctic stocks dealt with, such as summer spawning herring off Iceland, capelin stocks (Greenland/Iceland/Jan Mayen and the Barens Sea), sprat and other southern small pelagic stocks (e.g. anchovy, sardine and horse mackerel) dealt with are far less important in terms of 
biomass catches, butthey are important for the local economy of local economic importance and have a major ecological role to play in the NEA.

Sprat (Sprattus sprattus) follow regular seasonal migrations and occasionally form huge aggregations (Henderson and Henderson, 2017). Mackerel performs extensive annual migrations with distinct spawning, feeding, overwintering and nursery areas (Boyd et al., 2018; Brunel et al., 2018). Blue whiting performs seasonal and diel vertical migrations (Gonçalves et al., 2017). Herring also undergo extensive migrations between feeding and spawning grounds (Kotterba et al., 2017). Historical collapses and recoveries of pelagic fish stocks have been attributed to a combination of climate and fishing effects and, recruitment success (Planque et al., 2010; Fernandes et al., 2010; Fernandes et al., 2015). Besides, overexploitation has been found to decrease fish stock resilience to environmental variability and climate change (Anderson et al., 2008; Bates et al., 2014; Hsieh et al., 2006, Ottersen et al., 2006). Small and intermediate-size pelagic fish species are recognized as key elements in marine food chains (Cury et al., 2011; Kearney et al., 2012) and distribution changes could have significant conservation and management implications (Astthorsson et al., 2012).

The spawning ability and reproductive cycle of adult herring has often been linked to temperature conditions (Jennings and Beverton, 1991; Winters and Wheeler, 1996; MacKenzie et al., 2007), salinity (Rönkkönen et al., 2004) and food availability (Parmanne et al., 1994; Hufnagl and Peck, 2011). Herring stocks in the NEA tend to have inshore nursery areas (Geffen et al., 2011). Warmer temperature favoured higher sprat abundance (MacKenzie et al., 2007), whereas low salinity reduces its abundance despite the species' tolerance to a wide range of salinity (Peck et al., 2012). Adult mackerel also shows affinity to warm water (Beare and Reid, 2002; Jansen et al., 2012; Hughes et al., 2014; Bruge et al., 2016). Predation by mackerel is 
suggested to affect the distribution of blue whiting (e.g. Payne et al., 2012), and changes in distribution and abundance have also been associated with a strong subpolar gyre (Hátún et al., 2009; Payne et al., 2012) and associated oceanographic processes.

Ecosystem and population models based on size-spectrum theory (Blanchard et al., 2012; Jennings et al., 2008), habitat suitability theory (Kaschner et al., 2006; Phillips et al., 2006) or a combination of both (Fernandes et al., 2013a) are regularly used for projecting future scenarios of widely distributed fish species. These models suggest that temperature and primary production are often the main drivers of change in species' distribution and abundance at global (Jennings et al., 2008; Cheung et al., 2011; Barange et al., 2014; Chust et al., 2014) and regional scales (Fernandes et al., 2017; Fernandes et al., 2016; Speirs et al. 2016). However, despite capturing observed global decadal trends with some success (Fernandes et al., 2013; Jennings and Collingridge, 2016), these models are not precise and realistic enough to inform short-term fisheries management (Dickey-Collas et al., 2014). This is partly because these models do not consider all the drivers and local geographical characteristics that impact specific species or stocks (Planque et al., 2011). Despite the complexity of these models, there are still processes that may be underrepresented, such as top-down effects (Kearney et al., 2012), which are often represented as part of a mortality term. Future projections are not only impacted by uncertainties stemming from unresolved and uncertain processes in the models, but also by natural variability and scenario uncertainty (Payne et al., 2016; Cheung et al., 2016a, Mullon et al., 2016). These points highlight the limitations in predicting the future changes in species biomass and distribution, but it also shows that there is an increased capacity to consider longterm scenarios of change and its implications as well as the short-term forecast improvements (Fernandes et al., 2015; Trifonova et al., 2015). 
131 Considering the importance of widely distributed pelagic species, high mobility, their

132 sensitivity to environmental changes and exploitation patterns and their key role as prey to

133 other resources (Trenkel et al., 2014; Cury et al., 2000), this paper aims to assess the impact of

134 climate change on the long-term potential catches of the most abundant pelagic species and the

135 likely implications for fisheries management. 
137 A multispecies fisheries model (Fernandes et al., 2013a) which is a combination of a size138 spectrum model and a dynamic bioclimate envelope model (thereinafter the SS-DBEM) was used to provide estimates of fish production potential under climate change scenarios. SSDBEM is driven by the environmental variables obtained from two ocean biogeochemical models that are run under a low and high greenhouse gas emission scenario (RCP2.6 and RCP8.5) over the $21^{\text {st }}$ century considering multiple mechanisms summarized in Table I and described in following sections. Unless otherwise stated, we show 20-year averages of potential catches in the figures and tables to suppress the interannual-to-decadal variability of species, as we are interested in multi-decadal to centennial changes. However, figures with time-series show yearly values with the full modelled variability. The main data (results of model projections) is in the process of being made public through the European Copernicus service (https://climate.copernicus.eu/).

$\underline{\text { Species-based fish model }}$

We used the Dynamic Bioclimate Envelope Model (DBEM), a combined mechanisticstatistical approach that has been applied to a large number of marine species globally (Fernandes et al., 2013a; Mullon et al., 2016; Fernandes et al., 2017) and regionally (Jones et al., 2013; Fernandes et al., 2016; Fernandes et al., 2017). This model projects changes in species distribution and abundance with explicit consideration of mechanisms of population dynamics, dispersal (larval and adult) and ecophysiology (see Table I), under changes in ocean temperature, salinity, upwelling, sea-ice extent and habitats (Cheung et al., 2011; Cheung et al., 2016b) considering all the species distribution (not specific stocks of each species separately). Specifically, we employed a multi-species version of the model (SS-DBEM) that 
incorporated species interactions based on size-spectrum (SS) theory and habitat suitability, the SS-DBEM (Fernandes et al., 2013a). Therefore, the model considers predation and food availability through size-spectrum energy transfer from primary producers to consumers of progressively larger body size. Despite yearly outputs, pelagic species have two internal time steps to account for interannual seasonality and both, bottom and surface environmental drivers are considered since these species have pelagic and demersal life stages. For example, herring is a demersal spawner (Lambert and Ware, 1984; Axelsen et al., 2000) whereas mackerel, sprat and blue whiting are pelagic spawners (Coombs et al 1981; Lambert et al., 1984; Fréon et al., 2005).

Fishing practices are considered in relation to the concept of maximum sustainable yield (MSY; Table I). MSY is defined as the highest average theoretical equilibrium catch that can be continuously taken from a stock under average environmental conditions (Hilborn and Walters, 1992). In our application, the fishing mortality under MSY ( $\left.F_{M S Y}\right)$ values were obtained from FishBase (www.fishbase.org) assuming that $\mathrm{F}_{\mathrm{MSY}}$ is approximately equal to $0.4 * \mathrm{M}$ (natural mortality). This equation is used instead of the FMSY from stock assessments because SSDBEM models the whole species distribution (both inside and outside NEA) instead of modelling individual stocks. Therefore the whole species distribution (both inside and outside NEA) is modelled given that widely distributed species do not follow human management boundaries (Baudron et al., 2020). However, this equation values are in general consistent with values from stock assessments as reviewed below in the discussion section.

The larvae recruitment depends on temperature and currents that are known mechanisms affecting the mortality or success of herring, mackerel, blue whiting and sprat (Alvarez and 
Chifflet, 2012; Fernandes et al., 2015; Huse. 2016; Martin et al., 2016; Henderson and

Henderson, 2017). The model calculates larvae dispersal through ocean currents and diffusion assuming that pelagic larvae disperse passively from surrounding 'source' areas through ocean surface current and diffusion (Cheung et al., 2008; Table I). The magnitude of larval recruitment is dependent on pelagic larval duration (PLD), strength and direction of ocean currents and diffusivity (Table I). PLD, expressed in days, is calculated from an empirical equation established from a meta-analysis of PLD from 72 species of fish and invertebrates (O'Connor et al. 2007). Based on the calculated PLD and ocean current velocity data, the model calculates dispersal of pelagic larvae over time through diffusion and advection. Diffusion and advection of ocean currents are important factors determining dispersal of pelagic larvae of marine organisms (Possingham \& Roughgarden 1990; Gaylord \& Gaines 2000; Bradbury \& Snelgrove 2001; Gaines et al. 2003). The temporal and spatial patterns of pelagic larval dispersal were modelled by a two-dimensional advection-diffusion equation (Table I; Sibert et al. 1999; Gaylord \& Gaines 2000; Hundsdorfer \& Verwer 2003).

\section{$\underline{\text { Ocean biogeochemical models }}$}

Ocean environmental conditions from two ocean biogeochemical models of different complexity were used to force the species-based fisheries model SS-DBEM: the NEMOMEDUSA (NEMO, Nucleus for European Modelling of the Ocean and MEDUSA, Model of Ecosystem Dynamics, nutrient Utilisation, Sequestration and Acidification, Yool et al., 2013) and the GFDL ESM2M (GFDL, Geophysical Fluid Dynamics Laboratory and, ESM2, Earth 
System Model z coordinate, Dunne et al., 2012; Dunne et al., 2013).;.Both ocean biogeochemical models simulate changes in physical and biogeochemical ocean conditions over the historical period and the $21^{\text {st }}$ century under two different greenhouse gas scenarios (RCP2.6 and RCP8.5). These ocean conditions include seawater temperature, salinity, oxygen, alkalinity, primary production and horizontal and vertical water currents and affect the ecological processes in the SS-DBEM model such as the life-history, habitat, population dynamics and dispersal (Fernandes et al., 2013a; Queirós et al., 2016).

\section{NEMO-MEDUSA biogeochemical model}

The NEMO-MEDUSA is a global ocean model (Yool et al., 2013) with a half-degree ocean resolution. It simulates the physical environmental conditions and a size-structured ecosystem of small phytoplankton and zooplankton. The NEMO-MEDUSA explicitly includes the biogeochemical cycles of nitrogen, silicon and iron nutrients as well as the cycles of carbon which are not used directly by the fish model but influence the primary production. The NEMO-MEDUSA model was initialized using standard biogeochemical climatological fields (Garcia et al., 2010; Key et al., 2004) and simulated under surface atmospheric forcing derived from the Met Office Unified Model simulations (HadGEM2 configuration).

\section{GFDL biogeochemical model}

The GFDL ESM2M is a global coupled atmosphere-ocean general circulation model (Dunne et al. 2012, 2013) including a marine biogeochemistry model. The global ocean model has an approximately $1^{\circ}$ horizontal resolution and it describes the cycles of carbon, nitrogen, phosphorus, silicon, iron, oxygen, alkalinity and lithogenic material and considers three phytoplankton functional groups. 
232 The two ocean biogeochemical models were run under two greenhouse gas emission scenarios

233

234

235

236

237

238

239

240

241

242

243

244

(Moss et al., 2010): a strong mitigation scenario (Representative Concentration Pathways RCP2.6) with an atmospheric $\mathrm{CO}_{2}$ concentration of $421 \mathrm{ppm}$ by the end of the $21^{\text {st }}$ century, and "the business as usual" high greenhouse gas emissions scenario (RCP8.5) with atmospheric $\mathrm{CO}_{2}$ concentrations of $936 \mathrm{ppm}$ by the end of this century.

\section{Validation of the species projections}

Standardised and long-term fisheries surveys from 1977 to 2007, collated by Simpson et al. (2011), were used to cover the breadth of fisheries for this study. The survey data available for validation included AFBI Irish Sea Q1 and Q3, Cefas Celtic Sea, Cefas North Sea (autumn) and ICES IBTS North Sea (spring) datasets. The raw data are now freely available at the ICES website (www.ices.dk/marine-data/data-portals/Pages/DATRAS.aspx). Data from demersal surveys are widely used to estimate abundance (e.g. ICES, 2014d; Peck et al., 2013) and distribution (e.g. Huse et al., 2008; Jansen et al., 2012) of pelagic species. Given that blue whiting, sprat and herring have all been shown to undertake diel migrations (Cardinale et al., 2003; Post et al., 2019) resulting in greater day trawl catches (Petrakis et al., 2001) and that survey trawl data has been shown to be a reliable indicator of pelagic species abundance (Fig.4, Suppl. Mat.; Montero-Serra et al., 2015; ICES, 2015; Peck et al., 2013) and distribution (Huse et al., 2008; Jansen et al., 2012), the dataset used in this study are considered more reliable when compared to landings (herring) and acoustic (sprat) data (Fig.4, Suppl. Mat.; MonteroSerra et al., 2015). Despite these studies, it is acknowledged that bottom trawl surveys are not designed to target pelagic species, and that additional abundance estimates should be extracted from acoustic surveys (e.g. ICES, 2015). However, acoustic data is not consistently available 
over the study area and timeframe despite recent important advances in its harmonization and public availability are promising for its use in ecosystem modelling and validation. For example, the ICES Working Group on Acoustic and Egg Surveys for Sardine and Anchovy in ICES areas 7, 8 and 9 (WGACEGG) is developing a not yet public protocol with the title "Manual for Acoustic Surveys in Ices Areas 6, 7, 8 and 9".

The total number of individuals for each species was tallied across size classes for each survey haul. An average catchability estimate was applied to similar pelagic species for all size groups using total biomass and catch estimates from Sparholt (1990):

Corrected abundance $=$ uncorrected abundance $*(1 /$ catchability $)$

To control for the differing effort between surveys the swept area for each haul was calculated using estimates of wing-spread for Grand Ouverture Vertical (GOV) trawls from Fraser et al. (2007) multiplied by the distance over which the hauls were undertaken scaled to $\mathrm{km}^{2}$ following the equation:

Area swept $\mathrm{km}^{2}=(((6.85 *(\log ($ depth $)))+5.89) *$ distance $) / 1000000$

Depth and distance were measured in meters, being the distance based on haul duration and speed (assumed tow speed 4 knots for duration of haul, except for North Ireland data where the data is defined as the number of individuals $/ 3 \mathrm{~nm})$.

All the survey data is aggregated into a cell grid of $0.5 \times 0.5$ degrees to match the fish model grid. To compare projected changes with observations from surveys, a time-series per cell for 
each species have been compared. Besides, time-series aggregating all the spatial cells with survey data for each species is compared to estimate the long-term performance of wider areas. The time-series are normalized between 0 and 1 to consider that the model projects relative change and to have error estimates in an interval that are easier to understand. Since multiple species at multiple cells were considered, we needed to ensure that results are comparable, therefore,time-series of survey data with more than 3 years of missing data were not included. As a result, not enough data to assess the simulated changes in blue whiting was available. Then, time-series from the models were extracted for those years, species and cells where there was commonly available data from the surveys at the $0.5 \times 0.5$ degrees and yearly resolution. This restricted the data that could be analysed to the period from 1982 to 2007 (26 years) and the following 3 pelagic species (out of the 4 modelled here): herring, mackerel and sprat. These time-series were produced for both, the survey data and the model projections, and were compared by calculating the average error (AE) between them:

$294 \quad \mathrm{AE}=\frac{\sum_{\mathrm{j}}\left|\mathrm{p}_{\mathrm{j}}-\mathrm{s}_{\mathrm{j}}\right|}{\mathrm{j}}$,

where, $p$ is the biomass projected in the SS-DBEM model in a particular year for each species, and $s$ is the biomass from the survey and $j$ is the number of years with data. 


\section{Results}

\section{Performance of the fish projections}

300 General trends are well simulated by the models when aggregating over big areas (Table II and 301 Fig.2). However, local scale simulations are more complicated (grid cell level). Errors at cells 302 level range between 0.43 and 0.49 , whereas errors aggregating all the cells with survey data 303 drops to the range 0.23 to 0.41 (Table II). In general, projections for herring and mackerel using 304 GFDL biogeochemical model tend to have lower errors than projections using NEMOMEDUSA's output. However, sprat projections using the NEMO-MEDUSA model at both, cell and aggregated levels, are higher than those projected with the GFDL. Moreover, none of the differences between biogeochemical model projections is statistically significant (paired t-test). Therefore, it cannot be concluded that projections driven by a particular biogeochemical model are better than the other.

The large variance in the error highlights the need to consider the model projections as averages over periods (e.g. 20-year averages) instead of considering the modelled inter-annual variability. This can be observed in Figure 2 where variability projected by the model and that observed in surveys does not match at the year by year scale, however, similar decadal trends are observed. This outcome drives our approach of showing results as an ensemble of both model projections (Fig. 3) to show the inherent uncertainty from the projection of environmental variables in the biogeochemical models into the species model. 
321 Herring catches were projected to vary by $\pm 5-10 \%$ relative to the present day (2015) averaged over the North-East Atlantic, but the projections diverge between the two gas emission scenarios from 2070 onwards (Fig. 3a). Under the low greenhouse gas emission scenario, herring is projected to increase by up to $15 \%$ by the end of this century, while under the high greenhouse gas emission scenario, herring is projected to decrease by up to $35 \%$. On the contrary, mackerel was projected to increase in both future scenarios: up to 5-10\% until 2040 (Fig. 3b) and much higher increases $15-30 \%$ by the end of the century. The model simulates increases in catch trends for mackerel (Fig. 3b) and sprat (Fig. 3c). However, projections of sprat have larger uncertainties in the first decades than other species projections. Sprat would be benefited from changes in environmental conditions under a low gas emission scenario and showing the most significant differences across. Catch of blue whiting is projected to increase by up to $10 \%$ in a low emission scenario but it is projected to decrease by up to $40 \%$ under a high emission scenario (Fig. 3d). However, there is considerable uncertainty in projections under the high scenario and results need to analyse carefully.

Catch projections for all the pelagic species show consistent increases under a low emission scenario by the end of the century (Fig. 3). The projections under the high emissions scenarios, however, are more uncertain than low emission scenarios and sometimes do not even agree on the sign of changes. Herring and blue whiting show the lowest uncertainty in the medium term to 2040 (Fig. 3a,d), whereas mackerel and sprat show higher uncertainty in the medium term between 2040 and 2080 (Fig. 3b,c). The uncertainties in potential catches are mainly driven by the high uncertainty in primary production projections (Table III). Despite a general increase in temperature in all ICES areas, northern areas experience generally lower increases than 
southern areas in the shorter term (2020-2039). Primary production increases in areas II and III and decreases everywhere else despite high uncertainty. Area III, which contains the highest increases, shows the lowest uncertainty in terms of primary production estimates.

Figure 4 shows the changes in species distributions for the periods 2020-2039, 2050-2069 and 2080-2099 relative to the present baseline period (2000-2019) under the high-emission scenario. Blue whiting, herring and mackerel have a potential for habitat displacement towards the Arctic Ocean, with reductions in the southern area of distribution, especially for herring and blue whiting. For capelin there are no agreement between the models since GFDL projects in general slight increases for both emission scenarios with decadal oscillations, whereas Medusa show strong declines in the high emission scenarios for most of the ICES areas (higher declines in northern areas of NEA). Sprat shows a decline in catch potential in areas IV, VI and VII, but not a corresponding increase in northern regions. There is a consistent pattern showing that northern latitudes will benefit whereas southern areas will be negatively impacted in terms of all species catches. ICES area IIb is the area that shows the highest increases with gains in blue whiting, herring and sprat. Sprat increases are concentrated at the more southerly end of the northern regions IIa and V, areas that show other three species. Herring is expected to show the highest changes by $2020-2039$ and $2050-2069$, both positive and negative, in terms of the amount of area experiencing changes. Mackerel will be the second species more impacted by 2050-2069. blue whiting is projected to increase and sprat to decrease, with a few local exceptions. Herring and mackerel show the highest changes with dramatic northern shifting by the end of the century. Overall, the lower emission scenarios show similar spatial patterns in terms of areas of highest increases and decreases for each species with some differences: (i) slower rates of changes with almost no change by 2020-2039, (ii) changes in 2050-2069 similar to the high emission scenario between 2020-2039 and (iii) changes by the end of the century similar to the mid-century projections under the high emission scenario. The sparse catches 
369 have concentrated mostly in the south-western areas. However, the potential catches decrease 370 projected by the model in the future is consistent with the trend observed in the Baltic (ICES

371 area III) catch data. Therefore, the model cannot be trusted to forecast the distribution of species 372 precisely, but it is good for general trends over wide areas (e.g. ICES areas). 
375

376

377

378

379

380

381

382

383

384

385

386

387

388

389

390

391

392

393

394

395

396

397

398

\section{Discussion}

We show that under a MSY, the SS-DBEM projects a general increase in the potential catch for all widely distributed pelagic species in the short (by 2020) and the medium term (by midcentury), but a decrease for herring and blue whiting by the end of the century under a high emission scenario (RCP8.5). Potential catch increase is projected in northern areas but decreases in southern areas mainly due to changes in temperature and primary production (Table III) simulated by two ocean biogeochemical models in response to climate change. For example, both models simulate a decrease in the Atlantic Meridional Overturning circulation under global warming, which leads to an overall reduction of ocean heat transport to the high North Atlantic and as a result to a reduced warming south of Greenland (Winton et al., 2013).

Potential catch increases of pelagic species are projected over the $21^{\text {st }}$ century, despite negative trends in total primary production in NEA southern areas. However, total fish biomass can decrease as shown in other studies (Cheung et al., 2009; Lotze et al., 2019) while biomass of small fish species increases (e.g. pelagic species considered in this study). This is because at a higher temperature the steepness of the relationship between the primary production and fish abundance will increase (Fernandes et al., 2016a). Using a simple size-spectrum approach based on temperature and primary production (Jennings et al., 2008), an increase of $2^{\circ} \mathrm{C}$ in temperature (and at the same primary production level) can trigger a $20 \%$ decrease in total biomass, but an increase of smaller size fish abundance and biomass (Fernandes et al., 2016). This is consistent with higher trophic and benthic species projected to decrease as a result of warming and ocean acidification in southern areas of the NEA (Queirós et al., 2015; Fernandes et al., 2017, Lotze et al., 2019). The two biogeochemical models show agreement on the main trends and areas of impacts. The differences in the simulated physical and biogeochemical 
conditions between the two models under the same future scenario may be explained by internal natural variability uncertainty or model uncertainty (Walters et al., 2005; Hawkins and Sutton, 2009; Frölicher et al., 2016; Cheung et al., 2016a; Frölicher et al., 2016).

402

403

404

405

406

407

408

409

410

411

412

413

414

415

416

417

418

Figure 2 shows that we can trust more the model for herring and sprat because they are more able to reproduce the historical catches (goodness of fit), also considering that the SS-DBEM is not a statistical model where catch data has been used to drive the model (generalization power). However, it seems the model is less reliable for mackerel in comparison with the other species. Figure 2 does not show high uncertainty in the historical projections since there is small difference between the model run trends except for sprat that shows higher differences. Nevertheless, higher uncertainty is shown in the projections (Fig. 3), so that scenario uncertainty is expected to be higher than model internal variability. This study results are in agreement with empirical work which confirms that projected increases of mackerel in the Svalbard Archipelago (Berge et al., 2015). Furthermore, evidence of mackerel distribution changes in association with warmer temperatures across the North Atlantic have been recorded (Overholtz et al., 2011; Hughes et al., 2014; Montero-Serra et al., 2015(Montero-Serra et al., 2015). Sprat abundance and size has been declining since 1980 (Henderson and Henderson, 2017) due to changes in temperature and global climate patterns in the Bristol Channel which contains spawning and overwinter areas. A distribution shift of fish species can occur due to changes in habitat suitability, but there are additional processes involved (e.g. geographical attachment, species interactions or demographic structure) which are needed for a shift to happen or which can limit it (Planque et al., 2011). Therefore, a species may be able to move to new areas (Nøttestad et al., 2016) where it has not been previously observed or species can increase their abundance dramatically in areas where they have rarely observed due to density changes (Petitgas et al., 2012; Punzón et al., 2016). Both situations would produce a shift in the centroid of the species distribution. The SS-DBEM model used considers many of these 
processes as detailed in Planque et al. (2011). The modelled shift in distribution is determined by changes in predicted carrying capacity of the species in each grid cell, while its shifts are the result of the spatial population dynamics (Cheung et al., 2016b). Firstly, carrying capacity of the population in a cell is positively related to habitat suitability and the energy from primary production that is available for the species with consideration of competition between species in the same cell which can limit shifts speed (Fernandes et al., 2013). Secondly, diffusion of the populations is also related to the gradient of habitat suitability between adjacent cells, resulting in an increase in net diffusion out of the cell if habitat suitability in adjacent cells is higher. Thirdly, population recruitment is determined by the dispersal of larvae which is dependent on surface ocean advection and pelagic larval duration, the latter is a function of temperature. Thus, as ocean conditions change, these three processes result in the change in the distribution of abundance of the species.

The SS-DBEM model used do not account for the adaptation capacity of the species to changes in environmental conditions, due to the sparse knowledge available. This could slow the rate of changes or limit the spatial occurrence of these changes. Engelhard and Heino (2004) demonstrated substantial changes in phenotypic growth and maturation in herring, but a weak evolutionary response. While some studies investigate differences in spawning herring populations using genetic proxies (Jørgensen et al., 2005; King et al., 1987; McPherson et al., 2003), herring spawning tactics also appear to be influenced by phenotypic variability (Jennings and Beverton, 1991; Winters and Wheeler, 1996). Herring have probably adopted different spawning seasons as one of their survival strategies (Melvin et al., 2009; Sinclair and Tremblay, 1984). Although it is established that in herring the process of first maturation is triggered by a combination of physiological (size condition of fish) and environmental cues such as temperature (Winters and Wheeler, 1996) and photoperiodic cycles (McPherson and 
449 Kjesbu, 2012), the relative influence of genetics and environment on herring spawning

450

451

452

453

454

455

456

457

458

459

460

461

462

463

464

465

466

467

468

469

470

471

472

473 behaviour (i.e. seasonal strategy) remains unresolved. Similarly, no evidence of climate change-induced genetic selection was found by Heath et al. (2012).

Pelagic species have lower geographical barriers and higher capacities to change their distribution (Cheung et al., 2008; Trenkel et al., 2014) due to their wide distribution and pelagic habitat but they are also highly vulnerable to environmental variability, including multi-decadal regime shifts (Alheit et al., 2009; Barange et al., 2009; Chavez et al., 2003; Fernandes et al., 2010; Hsieh et al., 2009). This sensitivity to environmental variability is often linked to impacts on the recruitment success of pelagic species (Ibaibarriaga et al., 2007; Hátún et al., 2009; MacKenzie et al., 2012; Payne et al., 2013; Bruge et al., 2016; Tsoukali et al., 2016). Atlantic herring, mackerel and blue whiting are migratory species that occupies nursery grounds during the early life stages and then migrates to feeding grounds (Blaxter and Holliday, 1963; Corten, 2002; Ruzzante et al., 2006; Volkenandt et al., 2015). The areas of highest negative impact contain many of the key spawning areas of these pelagic species. For example, herring known spawning areas are in the East of Scotland and the Celtic sea (Damme and Bakker, 2014). Although, mackerel spawning areas from Iberian Peninsula to the West of Ireland and Scotland (Brunel et al., 2018) would be less affected, strong impacts in the southern spawning areas around Iberian Peninsula are projected. Blue whiting spawning areas in the West of Ireland and Scotland (Gonçalves et al., 2017) would be less affected with potential positive impacts on local spawning in the Norwegian coast and the coast of Iceland. Similarly, local herring spawning in Norwegian coast might become more suitable (Berg et al., 2017). These results agree with the increase of northern spawning areas already forecasted decades ago (Johnson, 1977). Geographical attachment of migratory pelagic species to nursery and spawning areas has been observed and discussed (Petitgas et al., 2006; Brunel et al., 2017). 
474 The life history characteristics of the pelagic species considered in this study render them 475 having low to moderate vulnerability to fishing (Cheung et al., 2005; see also www.fishbase.org). These vulnerabilities to environmental variability and fishing complicates

477 the assessment of the impacts of long-term climate change on these species, both in terms of 478 distribution shifts and mortality (Petitgas et al., 2012; Shephard et al., 2014). One of the main examples is the anchoveta (Engraulis ringens), whose catches are highly variable and strongly dependent on the state of the El Nino Southern Oscillation index (FAO, 2016). The intensive fishing impacts in the variations of the stock abundance contributing to the amplification of the change magnitude (Fréon et al., 2008).

Mackerel increases in northern latitudes have had direct economic consequences for Iceland, Greenland, Norway and Scotland and have raised disputes on catches allocations between these countries (Bazilchuk, 2010; Cendrowicz, 2010; Astthorsson et al. 2012; Jansen et al., 2016; Spijkers and Boonstra, 2017). Given the projected trends in mackerel and that other species may follow similar patterns, our work suggests that further disputes for widely distributed pelagic species quotas may occur, as other recent studies (Baudron et al., 2018). Brexit and politics can add difficulties to these tensions depending on the final agreement between UK and EU (Lubchenco and Grorud-Colvert, 2015; Boyes and Elliott, 2016). This could also have implications for fisheries of higher trophic level species that forage on pelagic species such as cod or haddock, marine mammals and seabirds (Köster et al., 2001; Mullowney and Rose, 2014). In addition, these species could follow the pelagic species shift causing further management issues, but also conservation problems with polar species (Renaud et al., 2012). 
Small pelagic fisheries in the Northeast Atlantic are managed partly by North-East Atlantic Fisheries Organization (NEAFC) and partly by the EU Common Fishery Policy, whose objective is to maintain or rebuild fish stocks to levels that can produce their MSY. This policy is already yielding stock improvements on European Atlantic fisheries (Cardinale et al., 2013), particularly in relation to widely distributed pelagic species (Fernandes and Cook, 2013). For example, Atlantic herring seems to have recovered from overexploitation faster than expected (Nash et al., 2009), though later studies have attributed the recovery to natural variability in the climate system (Drinkwater et al., 2014).

ICES advice works on the stock level for each species giving different values of fishing mortality under MSY for some of the evaluated stocks. Herring historical estimates of sustainable fishing mortality advice (i. e., Fmsy) for most of the stocks is 0.25 except for a couple of stocks with 0.15 and 0.35 values respectively (ICES Stock Summary Database; http://www.ices.dk). ICES summary database used to reports a value of 0.22 for the mackerel stock "mac-nea", the 2014 ICES advice report a value of 0.25 (ICES, 2014b) and the latest 2019 report shows a value of 0.23 (ICES, 2019a). For sprat the 2014 ICES advice report suggests the values 0.29 and the ranges $0.26-0.32$ (ICES, 2014a) with the latest advice decreasing these values to the range between 0.19 and 0.27 (ICES, 2019b). The value for blue whiting was increased from 0.18 to 0.30 (ICES, 2014c) and further to 0.32 recently (ICES,

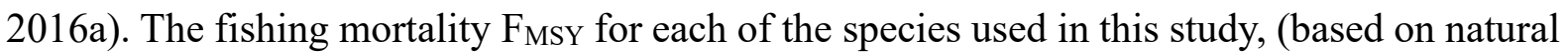
mortality) for herring, mackerel, blue whiting and sprat, is $0.21,0.26,0.18$ and 0.49 respectively. Most of these $\mathrm{F}$ values for the whole species distribution are close to the ones reported based on individual stock assessments above, despite for many stocks there is not yet a stablished Fmsy value in the stock assesment. There are still many mackerel, sprat and blue whiting stocks exploited above MSY levels or of unknown status (ICES, 2016a; ICES, 2019a; 
522 ICES, 2019b). Furthermore, research highlights the economic and ecological benefits of fishing 523 levels below MSY (Shephard et al., 2013; Voss et al., 2014; Da-Rocha and Mato-Amboage, 524 2015; Merino et al. 2015).

526 Due to the difficulties and lack of some stocks data aforementioned, the European Commission 527 is developing a proposal for a multi-stock multiannual plan for the management of fisheries in 528 the Baltic aiming at cod, herring and sprat (amending Council Regulation (EC) No 2187/2005 and repealing Council Regulation (EC) No 1098/2007). The need for multi-species approaches is not only recognized ecologically, but also for an effective ecosystem management approach (Möllmann et al., 2014). The SS-DBEM model considering trophic interactions for 49 species in the North Atlantic has shown a $20 \%$ slower latitudinal shift of species than in the singlespecies approach (Fernandes et al., 2013a). A recent study (Thorpe et al., 2015) highlights that multi-species MSY values can differ by $25-40 \%$ compared to the current single-species approaches which confirms previous concerns raised in Walters et al. (2015). Recent research suggest that forecast of climate change areas of impact can be used to inform multidisciplinary local spatial planning and stakeholder's actions for of climate-ready management (Fernandes et al., 2017; Queirós et al., 2016; Queirós et al., 2018). These climate-ready approaches use multiple ecosystem models and statistical analysis to identify potential areas where higher changes might occur to be considered by managers and industries in their planning. However, this adds further complexity to the need of transboundary agreements (ICES, 2016b; Krysov et al., 2017) which need to contemplate long-term considerations. 


\section{Acknowledgements}

545 The research was partly funded by the European Union's 7th Framework and the Horizon

5462020 programs under the MyFish (Grant Agreement No. 289257) and CERES (Grant

547 Agreement No. 678193) projects. T. L. Frölicher acknowledges financial support from the

548 Nippon-Foundation Nereus Program. Jose A. Fernandes work has been also funded by the

549 Gipuzkoa Talent Fellowships by Gipuzkoa Provincial Council. Paula Alvarez and Guillermo

550 Boyra provided useful insight on species biology and status of pelagic acoustic surveys. This

551 work also contributes to validate the new Marine Copernicus Climate Change Indicators

552 services (https://climate.copernicus.eu/).

553 
Alheit, J., Roy, C. \& Kifani, S. (2009) Decada-scale variability in populations. In: Checkley, D., Alheit, J., Oozeki, Y., Roy, C. (Eds.), Climate Change and Small Pelagic Fish Stocks. Cambridge University Press, p. 382.

Alvarez, P., \& Chifflet, M. (2012). The fate of eggs and larvae of three pelagic species, mackerel (Scomber scombrus), horse mackerel (Trachurus trachurus) and sardine (Sardina pilchardus) in relation to prevailing currents in the Bay of Biscay: Could they affect larval survival?. Scientia Marina, 76(3), 573-586.

Anderson, C. N., Hsieh, C. H., Sandin, S. A., Hewitt, R., Hollowed, A., Beddington, J., May, R. M., \& Sugihara, G. (2008). Why fishing magnifies fluctuations in fish abundance. Nature, 452(7189), 835-839. https://doi.org/10.1038/nature06851

Astthorsson, O. S., Valdimarsson, H., Gudmundsdottir, A., \& Óskarsson, G. J. (2012). Climate-related variations in the occurrence and distribution of mackerel (Scomber scombrus) in Icelandic waters. ICES Journal of Marine Science, 69(7), 1289-1297.

Axelsen, B. E., Nøttestad, L., Fernö, A., Johannessen, A., \& Misund, O. A. (2000). 'Await'in the pelagic: dynamic trade-off between reproduction and survival within a herring school splitting vertically during spawning. Marine Ecology Progress Series, 205, 259-269.

Barange, M., Bernal, M., Cercole, M.C., Cubillos, L., Cunningham, C.L., Daskalov, G.M., De Oliveira, J.A.A., Dickey-Collas, M., Hill, K., Jacobson, L., Køster, F.W., Masse, J., Nishida, H., Ñiquen, M., Oozeki, Y., Palomera, I., Saccardo, S.A., Santojanni, A., Serra, R., Somarakis, S., Stratoudakis, Y., van der Lingen, C.D., Uriarte, A. \& Yatsu, A. (2009) Current trends in the assessment and management of small pelagic fish stocks. In: Checkley, D., Alheit, J., Oozeki, Y., Roy, C. (Eds.), Climate Change and Small Pelagic Fish Stocks. Cambridge University Press, p. 382.

Barange, M., Merino, G., Blanchard, J. L., Scholtens, J., Harle, J., Allison, E. H., ... \& Jennings, S. (2014). Impacts of climate change on marine ecosystem production in societies dependent on fisheries. Nature Climate Change, 4(3), 211-216.

Bates, A. E., Pecl, G. T., Frusher, S., Hobday, A. J., Wernberg, T., Smale, D. A., ... \& Holbrook, N. J. (2014). Defining and observing stages of climate-mediated range shifts in marine systems. Global Environmental Change, 26, 27-38.

Baudron, A. R., \& Fernandes, P. G. (2015). Adverse consequences of stock recovery: European hake, a new "choke" species under a discard ban?. Fish and Fisheries, 16(4), 563-575.

Baudron, A. R., Brunel, T., Blanchet, M. A., Hidalgo, M., Chust, G., Brown, E. J., ... \& Fernandes, P. (2020). Changing fish distributions challenge the effective management of European fisheries. Ecography. https://doi.org/10.1111/ecog.04864.

Bazilchuk, N. (2010). Mackerel wars. Frontiers in Ecology and the Environment, 8(8), 397-397.

Beare, D.J. \& Reid, D.G. (2002) Investigating spatio-temporal change in spawning activity by Atlantic mackerel between 1977 and 1998 using generalized additive models. ICES Journal of Marine Science, 59,711-724.

Berg, F., Husebø, Å., Godiksen, J. A., Slotte, A., \& Folkvord, A. (2017). Spawning time of Atlantic herring (Clupea harengus) populations within a restricted area reflects their otolith growth at the larval stage. Fisheries Research, 194, 68-75.

Berge, J., Heggland, K., Lønne, O. J., Cottier, F., Hop, H., Gabrielsen, G. W., ... \& Misund, O. A. (2015). First records of Atlantic mackerel (Scomber scombrus) from the Svalbard archipelago, Norway, with possible explanations for the extensions of its distribution. Arctic, 54-61.

Boyd, R., Roy, S., Sibly, R., Thorpe, R., \& Hyder, K. (2018). A general approach to incorporating spatial and temporal variation in individual-based models of fish populations with application to Atlantic mackerel. Ecological Modelling, 382, 9-17.

Blanchard, J. L., Jennings, S., Holmes, R., Harle, J., Merino, G., Allen, J. I., ... \& Barange, M. (2012). Potential consequences of climate change for primary production and fish production in large marine ecosystems. Philosophical Transactions of the Royal Society B: Biological Sciences, 367(1605), 2979-2989.

Blaxter, J. H. S., \& Holliday, F. G. T. (1963). The behaviour and physiology of herring and other clupeids. In Advances in marine biology (Vol. 1, pp. 261-394). Academic Press.

Boyes, S. J., \& Elliott, M. (2014). Marine legislation-The ultimate 'horrendogram': International law, European directives \& national implementation. Marine pollution bulletin, 86(1-2), 39-47. 
Bradbury, I. R., \& Snelgrove, P. V. (2001). Contrasting larval transport in demersal fish and benthic invertebrates: the roles of behaviour and advective processes in determining spatial pattern. Canadian Journal of Fisheries and Aquatic Sciences, 58(4), 811-823.

Brunel, T., Van Damme, C. J., Samson, M., \& Dickey-Collas, M. (2018). Quantifying the influence of geography and environment on the northeast Atlantic mackerel spawning distribution. Fisheries Oceanography, 27(2), 159-173.

Bruge, A., Alvarez, P., Fontán, A., Cotano, U., \& Chust, G. (2016). Thermal Niche Tracking and Future Distribution of Atlantic Mackerel Spawning in Response to Ocean Warming. Frontiers in Marine Science, 3,86 .

Brunel, T., Van Damme, C. J., Samson, M., \& Dickey-Collas, M. (2018). Quantifying the influence of geography and environment on the northeast Atlantic mackerel spawning distribution. Fisheries oceanography, 27(2), 159-173.

Cardinale, M., Casini, M., Arrhenius, F., \& Håkansson, N. (2003). Diel spatial distribution and feeding activity of herring (Clupea harengus) and sprat (Sprattus sprattus) in the Baltic Sea. Aquatic Living Resources, 16(3), 283-292.

Cardinale, M., Dörner, H., Abella, A., Andersen, J. L., Casey, J., Döring, R., ... \& Stransky, C. (2013). Rebuilding EU fish stocks and fisheries, a process under way?. Marine Policy, 39, 43-52.

Cendrowicz, L. (2010). The Mackerel Wars: Europe's Fish Tiff With Iceland. Time, August 27.

Corten, A. (2002). The role of "conservatism"in herring migrations. Reviews in Fish Biology and Fisheries, 11(4), 339-361.

Chavez, F.P., Ryan, J., Lluch-Cota, S.E. \& Niquen, C.M. (2003) From anchovies to sardines and back: multidecadal change in the Pacific ocean. Science, 299, 217-221.

Cheung, W. W., Pitcher, T. J., \& Pauly, D. (2005). A fuzzy logic expert system to estimate intrinsic extinction vulnerabilities of marine fishes to fishing. Biological conservation, 124(1), 97-111 Cheung, W. W., Pitcher, T. J., \& Pauly, D. (2005). A fuzzy logic expert system to estimate intrinsic extinction vulnerabilities of marine fishes to fishing. Biological conservation, 124(1), 97-111.

Cheung, W. W. L., Lam, V. W. Y., \& Pauly, D. (2008). Modelling Present and Climate-Shifted Distribution of Marine Fishes and Invertebrates. Fisheries Centre Research Report 16 (3), University of British Columbia, Vancouver.

Cheung, W. W., Lam, V. W., Sarmiento, J. L., Kearney, K., Watson, R., \& Pauly, D. (2009). Projecting global marine biodiversity impacts under climate change scenarios. Fish and fisheries, 10(3), 235-251.

Cheung, W. W., Dunne, J., Sarmiento, J. L., \& Pauly, D. (2011). Integrating ecophysiology and plankton dynamics into projected maximum fisheries catch potential under climate change in the Northeast Atlantic. ICES Journal of Marine Science, 68(6), 1008-1018.

Cheung, W. W., Frölicher, T. L., Asch, R. G., Jones, M. C., Pinsky, M. L., Reygondeau, G., ... \& Watson, J. R. (2016a). Building confidence in projections of the responses of living marine resources to climate change. ICES Journal of Marine Science, 73(5), 1283-1296.

Cheung, W. W., Jones, M. C., Reygondeau, G., Stock, C. A., Lam, V. W., \& Frölicher, T. L. (2016b). Structural uncertainty in projecting global fisheries catches under climate change. Ecological Modelling, 325, 57-66.

Chust, G., Allen, J. I., Bopp, L., Schrum, C., Holt, J., Tsiaras, K., ... \& Daewel, U. (2014). Biomass changes and trophic amplification of plankton in a warmer ocean. Global Change Biology, 20(7), 2124-2139.

Coombs, S. H., Pipe, R. K., \& Mitchell, C. E. (1981). The vertical distribution of eggs and larvae of Blue whiting (Micromesistius poutassou) and Mackerel (Scomber scombrus in the eastern North Atlantic and North Sea. Rapports et Procès-Verbaux des Réunions du Conseil Permanent International pour l'Exploration de la Mer.

Cury, P., Bakun, A., Crawford, R. J., Jarre, A., Quinones, R. A., Shannon, L. J., \& Verheye, H. M. (2000). Small pelagics in upwelling systems: patterns of interaction and structural changes in "wasp-waist" ecosystems. ICES Journal of Marine Science, 57(3), 603-618.

Cury, P. M., Boyd, I. L., Bonhommeau, S., Anker-Nilssen, T., Crawford, R. J., Furness, R. W., ... \& Piatt, J. F. (2011). Global seabird response to forage fish depletion-one-third for the birds. Science, 334(6063), 1703-1706.

Da-Rocha JM, Mato-Amboage R (2015) On the benefits of including age structurein harvest control rules. Environ Resour Econ 64(4), 619-641.https://doi.org/10.1007/s10640-015-9891-3

Dickey-Collas, M., Payne, M. R., Trenkel, V. M., \& Nash, R. D. (2014). Hazard warning: model misuse ahead. ICES Journal of Marine Science: Journal du Conseil, 71(8), 2300-2306. 
Drinkwater, K. F., Miles, M., Medhaug, I., Otterå, O. H., Kristiansen, T., Sundby, S., \& Gao, Y. (2014). The Atlantic Multidecadal Oscillation: Its manifestations and impacts with special emphasis on the Atlantic region north of $60 \mathrm{~N}$. Journal of Marine Systems, 133, 117-130.

Dunne, J. P., John, J. G., Adcroft, A. J., Griffies, S. M., Hallberg, R. W., Shevliakova, E., Stouffer, R. J., Cooke, W., Dunne, K. A., Harrison, M. J., Krasting, J. P., Malyshev, S. L., Milly, P. C. D., Phillipps, P. J., Sentman, L. T., Samuels, B. L., Spelman, M. J., Winton, M., Wittenberg, A. T., \& Zadeh, N. (2012). GFDL's ESM2 global coupled climate-carbon Earth System Models. Part I: Physical formulation and baseline simulation characteristics. Journal of Climate, 25(19), 6646-6665.

Dunne, J. P., John, J. G., Shevliakova, E., Stouffer, R. J., Krasting, J. P., Malyshev, S. L., Milly, P. C. D., Sentman, L. T., Adcroft, A. J., Cooke, W., Dunne, K. A., Griffies, S. M., Hallberg, R. W., Harrison, M. J., Levy, H., Wittenberg, A. T., Phillips, P. J., \& Zadeh, N. (2013). GFDL's ESM2 Global Coupled Climate-Carbon Earth System Models. Part II: Carbon System Formulation and Baseline Simulation Characteristics. Journal of Climate, 26(7), 2247-2267.

Engelhard, G. H., \& Heino, M. (2004). Maturity changes in Norwegian spring-spawning herring Clupea harengus: compensatory or evolutionary responses? Marine Ecology Progress Series, 272, 245-256.

FAO (2016). The state of world fisheries and aquaculture 2016. Contributing to food security and nutrition for all. Rome. 200 pp.

Fernandes, J. A., Irigoien, X., Goikoetxea, N., Lozano, J. A., Inza, I., Pérez, A., \& Bode, A. (2010). Fish recruitment prediction, using robust supervised classification methods. Ecological Modelling, 221(2), 338352.

Fernandes, P.G., \& Cook, R.M. (2013). Reversal of fish stock decline in the Northeast Atlantic. Current Biology $23(15), 1432-1437$.

Fernandes, J. A., Cheung, W. W., Jennings, S., Butenschön, M., Mora, L., Frölicher, T. L, Barange M., \& Grant, A. (2013a). Modelling the effects of climate change on the distribution and production of marine fishes: accounting for trophic interactions in a dynamic bioclimate envelope model. Global change biology, 19, 2596-2607.

Fernandes, J. A., Lozano, J. A., Inza, I., Irigoien, X., Pérez, A., \& Rodríguez, J. D. (2013b). Supervised preprocessing approaches in multiple class variables classification for fish recruitment forecasting. Environmental modelling \& software, 40, 245-254.

Fernandes, J. A., Irigoien, X., Lozano, J. A., Inza, I., Goikoetxea, N., \& Pérez, A. (2015). Evaluating machinelearning techniques for recruitment forecasting of seven North East Atlantic fish species. Ecological Informatics, 25, 35-42.

Fernandes, J. A., Kay, S., Hossain, M. A., Ahmed, M., Cheung, W. W., Lazar, A. N., \& Barange, M. (2016). Projecting marine fish production and catch potential in Bangladesh in the 21st century under long-term environmental change and management scenarios. ICES Journal of Marine Science, 73(5), 1357-1369.

Fernandes, J. A., Papathanasopoulou, E., Hattam, C., Queirós, A. M., Cheung, W. W., Yool, A., ... \& Calosi, P. (2017). Estimating the ecological, economic and social impacts of ocean acidification and warming on UK fisheries. Fish and Fisheries, 18(3), 389-411.

Fraser, H. M., Greenstreet, S. P., \& Piet, G. J. (2007). Taking account of catchability in groundfish survey trawls: implications for estimating demersal fish biomass. ICES Journal of Marine Science, 64(9), 1800-1819.

Fréon, P., Cury, P., Shannon, L., \& Roy, C. (2005). Sustainable exploitation of small pelagic fish stocks challenged by environmental and ecosystem changes: a review. Bulletin of marine science, 76(2), 385-462.

Fréon, P., Bouchon, M., Mullon, C., García, C., \& Ñiquen, M. (2008). Interdecadal variability of anchoveta abundance and overcapacity of the fishery in Peru. Progress in Oceanography, 79(2-4), 401-412.

Frölicher, T. L., Rodgers, K. B., Stock, C. A., \& Cheung, W. W. (2016). Sources of uncertainties in 21 st century projections of potential ocean ecosystem stressors. Global Biogeochemical Cycles, 30(8), 1224-1243.

Gaines, S. D., Gaylord, B., \& Largier, J. L. (2003). Avoiding current oversights in marine reserve design. Ecological Applications, 13(sp1), 32-46.

Garcia, H. E., Locarnini, R. A., Boyer, T. P., Antonov, J. I., Zweng, M. M., Baranova, O. K., \& Johnson, D. R. (2010). World Ocean Atlas 2009, Volume 4: Nutrients (phosphate, nitrate, silicate), edited by: Levitus, S., NOAA Atlas NESDIS 71, US Government Printing Office, Washington DC, 398 pp., 2010.

Gaylord, B., \& Gaines, S. D. (2000). Temperature or transport? Range limits in marine species mediated solely by flow. The American Naturalist, 155(6), 769-789. 
Geffen, A. J., Nash, R. D., \& Dickey-Collas, M. (2011). Characterization of herring populations west of the British Isles: an investigation of mixing based on otolith microchemistry. ICES Journal of Marine Science, 68(7), 1447-1458.

Gonçalves, P., de Melo, A. Á., Murta, A. G., \& Cabral, H. N. (2017). Blue whiting (Micromesistius poutassou) sex ratio, size distribution and condition patterns off Portugal. Aquatic Living Resources, 30, 24.

Hátún, H., Payne, M. R., Beaugrand, G., Reid, P. C., Sandø, A. B., Drange, H., Hansen, B., Jacobsen, J.A., \& Bloch, D. (2009). Large bio-geographical shifts in the northeastern Atlantic Ocean: from the subpolar gyre, via plankton, to blue whiting and pilot whales. Progress in Oceanography, 80, 149-162.

Hawkins, E., \& Sutton, R. (2009). The potential to narrow uncertainty in regional climate predictions. Bulletin of the American Meteorological Society, 90(8), 1095-1107.

Heath, M. R., Neat, F. C., Pinnegar, J. K., Reid, D. G., Sims, D. W., \& Wright, P. J. (2012). Review of climate change impacts on marine fish and shellfish around the UK and Ireland. Aquatic Conservation: Marine and Freshwater Ecosystems, 22(3), 337-367.

Henderson, P. A., \& Henderson, R. C. (2017). Population regulation in a changing environment: Long-term changes in growth, condition and survival of sprat, Sprattus sprattus L. in the Bristol Channel, UK. Journal of sea research, 120, 24-34.

Hilborn R., \& Walters, C. J. (1992). Quantitative fisheries stock assessment: choice, dynamics and uncertainty. Chapman \& Hall, New York.

Hsieh C-h, Reiss CS, Hunter JR, Beddington JR, May RM, Sugihara G (2006) Fishing elevates variability in the abundance of exploited species. Nature, 443, 859.

Hsieh, C.-H., Kim, H. J., Watson, W., Di Lorenzo, E., \& Sugihara, G. (2009). Climate driven changes in abundance and distribution of larvae of oceanic fishes in the southern California region. Global Change Biology, 15, 2137-2152.

Hufnagl, M., \& Peck, M. A. (2011). Physiological individual-based modelling of larval Atlantic herring (Clupea harengus) foraging and growth: insights on climate-driven life-history scheduling. ICES Journal of Marine Science, 68(6), 1170-1188.

Hughes, K. M., Dransfeld, L., \& Johnson, M. P. (2014). Changes in the spatial distribution of spawning activity by north-east Atlantic mackerel in warming seas: 1977-2010. Marine Biology, 161(11), 2563-2576.

Hundsdorfer, W., \& Verwer, J. G. (2003). Numerical Solution of Time-dependent Advection-Diffusion-Reaction Equations.Springer, Berlin. 500 p.

Huse, G., Salthaug, A., \& Skogen, M. D. (2008). Indications of a negative impact of herring on recruitment of Norway pout. ICES Journal of Marine Science, 65(6), 906-911.

Huse, G., Fernö, A., \& Holst, J. C. (2010). Establishment of new wintering areas in herring co-occurs with peaks in the 'first time/repeat spawner'ratio. Marine Ecology Progress Series, 409, 189-198.

Huse, G. (2016). A spatial approach to understanding herring population dynamics. Canadian Journal of Fisheries and Aquatic Sciences, 73(2), 177-188.

Ibaibarriaga, L., Irigoien, X., Santos, M., Motos, L., Fives, J. M., Franco, C., ... \& Eltink, G. (2007). Egg and larval distributions of seven fish species in north-east Atlantic waters. Fisheries Oceanography, 16(3), 284293.

ICES (International Council for the Exploration of the Sea) (2013). Report of the herring assessment working group for the area South of 62N (HAWG). 2013/ACOM:06. pp. 1283.

ICES (International Council for the Exploration of the Sea) (2014a). EU request on preliminary FMSY ranges for Baltic cod, herring and sprat stocks. ICES Advice 2014, Book 11; 2014. Report of the ICES Advisory Committee on Fishery Management, Advisory Committee on the Marine Environment and Advisory Committee on Ecosystems, 2014. p. 2.

ICES (International Council for the Exploration of the Sea) (2014b). Widely Distributed and Migratory Stocks Mackerel in the Northeast Atlantic (combined Southern, Western, and North Sea spawning components). ICES Advice 2014, Book 9; 2014. Update advice for 2014. Report of the ICES Advisory Committee on Fishery Management, Advisory Committee on the Marine Environment and Advisory Committee on Ecosystems, 2014. p. 4.

ICES (International Council for the Exploration of the Sea). (2014c). Report of the Working Group on Widely Distributed Stocks (WGWIDE). Copenhagen: ICES CM 2014/ACOM:15, 971.

ICES (International Council for the Exploration of the Sea) (2014d). Report of the benchmark workshop on sprat stocks (WKSPRAT), 11-15 February 2013, Copenhagen, Denmark. ICES CM 2013/ACOM: 48. 
ICES (International Council for the Exploration of the Sea) (2015). Manual for International Pelagic Surveys (IPS). Working Group of International Pelagic Surveys. Series of ICES Survey Protocols SISP 9 - IPS. 92 pp.

ICES (International Council for the Exploration of the Sea) (2016a). Report of the Workshop on Blue Whiting Long Term Management Strategy Evaluation (WKBWMS), 30 August 2016, ICES HQ, Copenhagen, Denmark. ICES CM 2016/ACOM:53. 104 pp.

ICES (International Council for the Exploration of the Sea) (2016b). Report of the Working Group on Fish Distribution Shifts (WKFISHDISH), 22-25 November 2016, ICES HQ, Copenhagen, Denmark. ICES CM 2016/ACOM: 55. 197 pp.

ICES (International Council for the Exploration of the Sea) (2019a). Interbenchmark Workshop on the assessment of northeast Atlantic mackerel (IBPNEAMac). ICES Scientific Reports, 1:5. 71 pp. https://doi.org/10.17895/ices.pub.4985.

ICES (International Council for the Exploration of the Sea) (2019). Sprat (Sprattus sprattus) in subdivisions 2232 (Baltic Sea). In Report of the ICES Advisory Committee, 2019. ICES Advice 2019, spr.27.22-32, https://doi.org/10.17895/ices.advice.4754

Jansen, T., Campbell, A., Kelly, C., Hatun, H., \& Payne, M. R. (2012). Migration and fisheries of North East Atlantic Mackerel (Scomber scombrus) in autumn and winter. PLoS One, 7(12), e51541.

Jansen, T., Post, S., Kristiansen, T., Óskarsson, G. J., Boje, J., MacKenzie, B. R., ... \& Siegstad, H. (2016). Ocean warming expands habitat of a rich natural resource and benefits a national economy. Ecological Applications, 26(7), 2021-2032.

Jennings, S. \& Beverton, R. J. H. (1991). Intraspecific variation in the life history tactics of Atlantic herring (Clupea harengus L.) stocks. ICES Journal of Marine Science, 48(1), 117-125.

Jennings, S., Mélin, F., Blanchard, J. L., Forster, R. M., Dulvy, N. K., \& Wilson, R. W. (2008). Global-scale predictions of community and ecosystem properties from simple ecological theory. Proceedings of the Royal Society B: Biological Sciences, 275(1641), 1375-1383.

Jennings, S., \& Collingridge, K. (2015). Predicting consumer biomass, size-structure, produc-tion, catch potential, responses to fishing and associated uncertainties in the world's ma-rine ecosystems. PloS one, 10(7), $\mathrm{e} 0133794$.

Johnson, P. O. (1977). A review of spawning in the North atlantic mackerel, Scomber scombrus. Ministry of Agriculture Fisheries and Food, Directorate of Fisheries Research.

Jones, M. C., Dye, S. R., Fernandes, J. A., Frölicher, T. L., Pinnegar, J. K., Warren, R., \& Cheung, W. W. (2013). Predicting the impact of climate change on threatened species in UK waters. PLoS One, 8(1), e54216.

Jørgensen, H. B., Hansen, M. M., Bekkevold, D., Ruzzante, D. E., \& Loeschcke, V. (2005). Marine landscapes and population genetic structure of herring (Clupea harengus L.) in the Baltic Sea. Molecular Ecology, 14(10), 3219-3234.

Kaschner, K., Watson, R., Trites, A. W., \& Pauly, D. (2006). Mapping world-wide distributions of marine mammal species using a relative environmental suitability (RES) model. Marine Ecology Progress Series, 316, 285-310.

Kearney, K. A., Stock, C., Aydin, K., \& Sarmiento, J. L. (2012). Coupling planktonic ecosystem and fisheries food web models for a pelagic ecosystem: Description and validation for the subarctic Pacific. Ecological Modelling, 237, 43-62.

King, D. P. F., Ferguson, A., \& Moffett, I. J. J. (1987). Aspects of the population genetics of herring, Clupea harengus, around the British Isles and in the Baltic Sea. Fisheries Research, 6(1), 35-52.

Köster, F. W., Möllmann, C., Neuenfeldt, S., John, M. A. S., Plikshs, M., \& Voss, R. (2001). Developing Baltic cod recruitment models. I. Resolving spatial and temporal dynamics of spawning stock and recruitment for cod, herring, and sprat. Canadian Journal of Fisheries and Aquatic Sciences, 58(8), 1516-1533.

Key, R. M., Kozyr, A., Sabine, C. L., Lee, K., Wanninkhof, R., Bullister, J. L., Feely, R. A., Millero, F. J., Mordy, C., \& Peng, T.-H. (2004). A global ocean carbon climatology: results from Global Data Analysis Project (GLODAP), Global Biogeochemical Cycles 18 (4).

Kotterba, P., Moll, D., Hammer, C., Peck, M. A., Oesterwind, D., \& Polte, P. (2017). Predation on Atlantic herring (Clupea harengus) eggs by the resident predator community in coastal transitional waters. Limnology and Oceanography, 62(6), 2616-2628.

Krysov, A. I., Pronyuk, A. A., \& Rybakov, M. O. (2017). The international regulation of herring, blue whiting and mackerel fishery. In Proceedings of the MSTU (Vol. 20, No. 2, pp. 422-433). Directory of Open Access Journals. 
Lambert, T. C., \& Ware, D. M. (1984). Reproductive strategies of demersal and pelagic spawning fish. Canadian Journal of Fisheries and Aquatic Sciences, 41(11), 1565-1569.

Lotze HK, Tittensor DP, Bryndum-Buchholz A et al. (2019) Global ensemble projections reveal trophic amplification of ocean biomass declines with climate change. Proceedings of the National Academy of Sciences, 116, 12907-12912.

Lubchenco, J., \& Grorud-Colvert, K. (2015). Making waves: The science and politics of ocean protection. Science, 350,382 .

MacKenzie, B. R., Gislason, H., Möllmann, C., \& Köster, F. W. (2007). Impact of 21st century climate change on the Baltic Sea fish community and fisheries. Global Change Biology, 13(7), 1348-1367.

MacKenzie, B. R., Meier, H. M., Lindegren, M., Neuenfeldt, S., Eero, M., Blenckner, T., ... \& Niiranen, S. (2012). Impact of climate change on fish population dynamics in the Baltic Sea: a dynamical downscaling investigation. Ambio, 41(6), 626-636.

Martin, P., Maynou, F., Recasens, L., \& Sabatés, A. (2016). Cyclic fluctuations of blue whiting (Micromesistius poutassou) linked to open-sea convection processes in the northwestern Mediterranean. Fisheries Oceanography, 25(3), 229-240.

McPherson, L. R., \& Kjesbu, O. S. (2012). Emergence of an oocytic circumnuclear ring in response to increasing day length in Atlantic herring (Clupea harengus). Marine biology, 159(2), 341-353.

Melvin, G. D., Stephenson, R. L., \& Power, M. J. (2009). Oscillating reproductive strategies of herring in the western Atlantic in response to changing environmental conditions. ICES Journal of Marine Science, 66, 1784-1792.

Merino, G., Barange, M., Fernandes, J. A., Mullon, C., Cheung, W., Trenkel, V., \& Lam, V. (2014). Estimating the economic loss of recent North Atlantic fisheries management. Progress in Oceanography, 129, 314323.

Merino, G., Quetglas, A., Maynou, F., Garau, A., Arrizabalaga, H., Murua, H.,Santiago, J., Barange, M., Prellezo, R., García, D., Lleonart, J., Tserpes, G.,Maravelias, C., Carvalho, N., Austen, M., Fernandes, J. A., Oliver, P., \& Grau, A. M. (2015). Improving the performance of a Mediterranean demersal fishery toward economic objectives beyond MSY. Fisheries Research, 161, 131-144.

Möllmann, C., Lindegren, M., Blenckner, T., Bergström, L., Casini, M., Diekmann, R., Flinkman, J., MüllerKarulis, B., Neuenfeldt, S., Schmidt, J.O., \& Tomczak, M. (2014). Implementing ecosystem-based fisheries management: from single-species to integrated ecosystem assessment and advice for Baltic Sea fish stocks. ICES Journal of Marine Science, 71(5), 1187-1197.

Montero-Serra, I., Edwards, M., \& Genner, M. J. (2015). Warming shelf seas drive the subtropicalization of European pelagic fish communities. Global change biology, 21(1), 144-153.

Moss, R. H., Edmonds, J. A., Hibbard, K. A., Manning, M. R., Rose, S. K., Van Vuuren, D. P., ... \& Meehl, G. A. (2010). The next generation of scenarios for climate change research and assessment. Nature, 463(7282), 747-756.

Mullon, C., Steinmetz, F., Merino, G., Fernandes, J. A., Cheung, W. W. L., Butenschön, M., \& Barange, M. (2016). Quantitative pathways for Northeast Atlantic fisheries based on climate, ecological-economic and governance modelling scenarios. Ecological modelling, 320, 273-291.

Mullowney, D. R., \& Rose, G. A. (2014). Is recovery of northern cod limited by poor feeding? The capelin hypothesis revisited. ICES Journal of Marine Science, 71(4), 784-793.

Nash, J.F., Dickey-Collas, M., \& Kell, L.T. (2009). Stock and recruitment in North Sea herring (Clupea harengus); compensation and depensation in the population dynamics. Fisheries Research, 95, 88-97.

Nøttestad, L., Utne, K. R., Óskarsson, G. J., Jónsson, S. P., Jacobsen, J. A., Tangen, Ø., ... \& Debes, H. (2016). Quantifying changes in abundance, biomass, and spatial distribution of Northeast Atlantic mackerel (Scomber scombrus) in the Nordic seas from 2007 to 2014. ICES Journal of Marine Science: Journal du Conseil, 73(2), 359-373.

O'Connor, M. I., Bruno, J. F., Gaines, S. D., Halpern, B. S., Lester, S. E., Kinlan, B. P., \& Weiss, J. M. (2007). Temperature control of larval dispersal and the implications for marine ecology, evolution, and conservation. Proceedings of the National Academy of Sciences, 104(4), 1266-1271.

Ottersen, G., Hjermann, D.Ø., \& Stenseth, N.C. (2006). Changes in spawning stock structure strengthen the link between climate and recruitment in a heavily fished cod (Gadus morhua) stock. Fisheries Oceanography, 15(3), 230-243. 
Overholtz, W. J., Hare, J. A., \& Keith, C.M. (2011). Impacts of Interannual Environmental Forcing and climate change on the distribution of Atlantic mackerel on the U.S. Northeast continental shelf. Marine and Coastal Fisheries, 3, 219-232.

Parmanne, R., Rechlin, O., \& Sjöstrand, B. (1994). Status and future of herring and sprat stocks in the Baltic Sea. Dana, 10, 29-59.

Pauly, D. (1980). On the interrelationships between natural mortality, growth parameters and mean environmental temperature in 175 fish stocks. ICES Journal of Marine Science, 39, 175-192.

Pauly, D. (2010). Gasping fish and panting squids: Oxygen, temperature and the growth of water-breathing animals. In O. Kinne (Ed.), Excellence in ecology (Vol. 22). Oldendorf/Luhe, Germany: International Ecology Institute, 216 pp. ISBN-10: 3946729223.

Payne, M. R., Egan, A., Fässler, S. M., Hátún, H., Holst, J. C., Jacobsen, J. A., Slotte, A., \& Loeng, H. (2012). The rise and fall of the NE Atlantic blue whiting (Micromesistius poutassou). Marine Biology Research, 8(5-6), 475-487.

Payne, M. R., Ross, S. D., Clausen, L. W., Munk, P., Mosegaard, H., \& Nash, R. D. (2013). Recruitment decline in North Sea herring is accompanied by reduced larval growth rates. Marine Ecology Progress Series, 489, 197-211.

Payne, M. R., Barange, M., Cheung, W. W., MacKenzie, B. R., Batchelder, H. P., Cormon, X., ... \& Link, J. S. (2016). Uncertainties in projecting climate-change impacts in marine ecosystems. ICES Journal of Marine Science, 73(5), 1272-1282.

Peck, M. A., Kanstinger, P., Holste, L., \& Martin, M. (2012). Thermal windows supporting survival of the earliest life stages of Baltic herring (Clupea harengus). ICES Journal of Marine Science, 69(4), 529-536.

Peck, M. A., Reglero, P., Takahashi, M., \& Catalán, I. A. (2013). Life cycle ecophysiology of small pelagic fish and climate-driven changes in populations. Progress in Oceanography, 116, 220-245.

Petrakis, G., MacLennan, D. N., \& Newton, A. W. (2001). Day-night and depth effects on catch rates during trawl surveys in the North Sea. ICES Journal of Marine Science, 58(1), 50-60.

Petitgas, P., Reid, D., Planque, B., Nogueira, E., O’Hea, B., \& Cotano, U. (2006). The entrainment hypothesis: an explanation for the persistence and innovation in spawning migrations and life cycle spatial patterns. ICES Document CM.

Petitgas, P., Alheit, J., Peck, M. A., Raab, K., Irigoien, X., Huret, M., van derKooij, J., Pohlmann, T., Wagner, C., Zarraonaindia, I., \& Dickey-Collas, M. (2012). Anchovy population expansion in the North Sea. Marine Ecology Progress Series, 444, 1-13.

Phillips, S. J., Anderson, R. P., \& Schapire, R. E. (2006). Maximum entropy modeling of species geographic distributions. Ecological modelling, 190(3-4), 231-259.

Planque, B., Fromentin, J.M., Cury, P., Drinkwater, K.F., Jennings, S., Perry, R.I., \& Kifani, S. (2010). How does fishing alter marine populations and ecosystems sensitivity to climate?. Journal of Marine Systems, 79(3), 403-417.

Planque, B., Loots, C., Petitgas, P., LindstrøM, U. L. F., \& Vaz, S. (2011). Understanding what controls the spatial distribution of fish populations using a multi-model approach. Fisheries Oceanography, 20(1), 1-17.

Possingham, H. P., \& Roughgarden, J. (1990). Spatial Population Dynamics of a Marine Organism with a Complex Life Cycle: Ecological Archives E071-001. Ecology, 71(3), 973-985.

Post, S., Fock, H. O., \& Jansen, T. (2019). Blue whiting distribution and migration in Greenland waters. Fisheries Research, 212, 123-135.

Punzón, A., Serrano, A., Sánchez, F., Velasco, F., Preciado, I., González-Irusta, J. M., \& López-López, L. (2016). Response of a temperate demersal fish community to global warming. Journal of Marine Systems, 161, 110.

Queirós, A. M., Fernandes, J. A., Faulwetter, S., Nunes, J., Rastrick, S. P., Mieszkowska, N., ... \& Findlay, H. S. (2015). Scaling up experimental ocean acidification and warming research: from individuals to the ecosystem. Global change biology, 21(1), 130-143.

Queirós, A. M., Fernandes, J., Genevier, L., \& Lynam, C. P. (2018). Climate change alters fish community sizestructure, requiring adaptive policy targets. Fish and Fisheries, 19(4), 613-621.

Queirós, A. M., Huebert, K. B., Keyl, F., Fernandes, J. A., Stolte, W., Maar, M., ... \& Vermard, Y. (2016). Solutions for ecosystem-level protection of ocean systems under climate change. Global Change Biology, 22(12), 3927-3936. 
Renaud, P. E., Berge, J., Varpe, Ø., Lønne, O. J., Nahrgang, J., Ottesen, C., \& Hallanger, I. (2012). Is the poleward expansion by Atlantic cod and haddock threatening native polar cod, Boreogadus saida?. Polar Biology, 35(3), 401-412.

Rönkkönen, S., Ojaveer, E., Raid, T., \& Viitasalo, M. (2004). Long-term changes in Baltic herring (Clupea harengus membras) growth in the Gulf of Finland. Canadian Journal of Fisheries and Aquatic Sciences, 61(2), 219-229.

Ruzzante, D. E., Mariani, S., Bekkevold, D., André, C., Mosegaard, H., Clausen, L. A., ... \& Brigham, J. (2006). Biocomplexity in a highly migratory pelagic marine fish, Atlantic herring. Proceedings of the Royal Society of London B: Biological Sciences, 273(1593), 1459-1464.

Shephard, S., Fung, T., Rossberg, A. G., Farnsworth, K. D., Reid, D. G., Greenstreet, S. P., \& Warnes, S. (2013). Modelling recovery of Celtic Sea demersal fish community size-structure. Fisheries Research, 140, 91-95.

Shephard, S., Rindorf, A., Dickey-Collas, M., Hintzen, N. T., Farnsworth, K., \& Reid, D. G. (2014). Assessing the state of pelagic fish communities within an ecosystem approach and the European Marine Strategy Framework Directive. ICES Journal of Marine Science, 71(7), 1572-1585.

Sibert, J. R., Hampton, J., Fournier, D. A., \& Bills, P. J. (1999). An advection-diffusion-reaction model for the estimation of fish movement parameters from tagging data, with application to skipjack tuna (Katsuwonus pelamis). Canadian journal of fisheries and aquatic sciences, 56(6), 925-938.

Simpson, S. D., Jennings, S., Johnson, M. P., Blanchard, J. L., Schön, P. J., Sims, D. W., \& Genner, M. J. (2011). Continental shelf-wide response of a fish assemblage to rapid warming of the sea. Current Biology, 21(18), 1565-1570.

Sinclair, M., \& Tremblay, M. J. (1984). Timing of spawning of Atlantic herring (Clupea harengus harengus) populations and the match-mismatch theory. Canadian Journal of Fisheries and Aquatic Sciences, 41(7), $1055-1065$

Sparholt, H. (1990). An estimate of the total biomass of fish in the North Sea. Journal du Conseil: ICES Journal of Marine Science, 46(2), 200-210.

Speirs, D. C., Greenstreet, S. P., \& Heath, M. R. (2016). Modelling the effects of fishing on the North Sea fish community size composition. Ecological Modelling, 321, 35-45.

Spijkers, J., \& Boonstra, W. J. (2017). Environmental change and social conflict: the northeast Atlantic mackerel dispute. Regional Environmental Change, 17(6), 1835-1851.

Thorpe, R. B., Le Quesne, W. J., Luxford, F., Collie, J. S., \& Jennings, S. (2015). Evaluation and management implications of uncertainty in a multispecies size-structured model of population and community responses to fishing. Methods in Ecology and Evolution, 6(1), 49-58.

Trenkel, V. M., Huse, G., MacKenzie, B. R., Alvarez, P., Arrizabalaga, H., Castonguay, M., ... \& Jacobsen, J. A. (2014). Comparative ecology of widely distributed pelagic fish species in the North Atlantic: implications for modelling climate and fisheries impacts. Progress in Oceanography, 129, 219-243.

Trifonova, N., Kenny, A., Maxwell, D., Duplisea, D., Fernandes, J., \& Tucker, A. (2015). Spatio-temporal Bayesian network models with latent variables for revealing trophic dynamics and functional networks in fisheries ecology. Ecological Informatics, 30, 142-158.

Tsoukali, S., Visser, A. W., \& MacKenzie, B. R. (2016). Functional responses of North Atlantic fish eggs to increasing temperature. Marine Ecology Progress Series, 555, 151-165.

van Damme, C. J., \& Bakker, C. (2014). Herring larvae surveys 2012-2013: Survey reports and results (No. 14.001). IMARES.

Volkenandt, M., Berrow, S., O’Connor, I., Guarini, J. M., \& O’Donnell, C. (2015). Prespawning herring distribution in the Irish Celtic Sea between 2005 and 2012. ICES Journal of Marine Science, 72(2), 498507.

Voss, R., Quaas, M., Schmidt, J. O., \& Hoffmann, J. (2014). Regional trade-offs from multi-species maximum sustainable yield (MMSY) management options. Marine Ecology Progress Series, 498, 1-12.

Walters, C. J., Christensen, V., Martell, S. J., \& Kitchell, J. F. (2005). Possible ecosystem impacts of applying MSY policies from single-species assessment. ICES Journal of Marine Science, 62(3), 558-568.

Winters, G. H., \& Wheeler, J. P. (1996). Environmental and phenotypic factors affecting the reproductive cycle of Atlantic herring. ICES Journal of Marine Science, 53(1), 73-88.

Winton, M., Griffies, S. M., Samuels, B. L., Sarmiento, J. L., \& Frölicher, T. L. (2013). Connecting changing ocean circulation with changing climate. Journal of climate, 26(7), 2268-2278. 
Yool, A., Popova, E. E., \& Anderson, T. R. (2013). MEDUSA-2.0: an intermediate complexity biogeochemical model of the marine carbon cycle for climate change and ocean acidification studies. Geoscientific Model Development, 6(5), 1767-1811. 
986 Table I. Table summarizing the main equations and parameters to consider the species 987 mechanisms in SS-DBEM. Further details in associated references.

\begin{tabular}{|c|c|c|}
\hline Mechanism & Equation & Parameters \\
\hline $\begin{array}{l}\text { Growth }=\text { anabolism }- \\
\text { catabolism } \\
\text { (Pauly 2010; Cheung et al., } \\
\text { 2011) }\end{array}$ & $\begin{array}{l}\mathrm{G}=\mathrm{HW}^{\mathrm{a}}-\mathrm{kW} \\
\mathrm{H}=\mathrm{g}\left[\mathrm{O}_{2}\right] * \mathrm{e}^{-\mathrm{j} 1 / \mathrm{T}} \\
\mathrm{k}=\mathrm{h}\left[\mathrm{H}^{+}\right] * \mathrm{e}^{-\mathrm{j} 2 / \mathrm{T}}\end{array}$ & $\begin{array}{l}\mathrm{H}=\text { anabolism coefficient } \\
\mathrm{k}=\text { catabolism coefficient } \\
\mathrm{W}=\text { body weight } \\
\mathrm{a}=\text { anabolism exponent }(0.5 \text { to } 0.95) \\
\mathrm{W}_{\infty}=\text { asymptotic weight } \\
\text { The coefficients g and h were derived from } \\
\text { the average } \mathrm{W}_{1}, \mathrm{~K} \text {, and environmental } \\
\text { temperature }(\mathrm{T}) \text { of the species reported in the } \\
\text { literature. }\end{array}$ \\
\hline Length-Weight & $\mathrm{W}=\mathrm{a} * \mathrm{~L}^{\mathrm{b}}$ & $\begin{array}{l}\mathrm{W}=\text { weight } \\
\mathrm{L}=\text { length }\end{array}$ \\
\hline $\begin{array}{l}\text { Size-spectrum production } \\
\text { (Jennings et al., 2008; } \\
\text { Fernandes et al., 2013) }\end{array}$ & $\mathrm{P}=\exp (25.22-\mathrm{E} / \mathrm{kT}) * \mathrm{~W}^{0.76}$ & $\begin{array}{l}\mathrm{E}=\text { activation energy of metabolism } \\
\mathrm{k}=\text { Boltzmann's constant } \\
\mathrm{T}=\text { temperature in Kelvin }\left({ }^{\circ} \mathrm{C}+273\right)\end{array}$ \\
\hline $\begin{array}{ll}\text { Intrinsic } & \text { population } \\
\text { growth rate } & \text { (Hilborn \& } \\
\text { Walters, 1992) } & \end{array}$ & $\mathrm{G}=\mathrm{r} * \mathrm{~A} *(1-(\mathrm{A} / \mathrm{KC}))$ & $\begin{array}{l}\mathrm{r}=\text { intrinsic rate of population increase } \\
\mathrm{A}=\text { the relative abundance } \\
\mathrm{KC}=\text { population carrying capacity }\end{array}$ \\
\hline $\begin{array}{l}\text { Larval recruitment } \\
\text { (O'Connor et al., 2007; } \\
\text { Cheung et al., 2008) }\end{array}$ & $\begin{array}{l}\ln (P L D)=\beta_{0}-1368 \cdot\left(\ln \left(T / T_{c}\right)\right)-0.283_{2} \cdot\left(\ln \left(T / T_{c}\right)\right)^{2} \\
\beta_{0}=0.739+0.739 \cdot(\ln (T)+0.714 \cdot(D M) \\
\overline{\ln (T)}=\frac{\sum_{i=1}^{N} \ln \left(T_{i}\right)}{N}\end{array}$ & $\begin{array}{l}\text { PLD = pelagic larvae duration } \\
\mathrm{T}=\text { surface temperature } \\
\mathrm{Tc}=15 \mathrm{C} \\
\mathrm{DM} \text { is the developmental type of larvae } \\
(0 \text { lecithotrophic, } 1 \text { planktotrophic }) \\
\mathrm{N}=\text { number of cells where species occur }\end{array}$ \\
\hline $\begin{array}{l}\text { Larval dispersal } \\
\text { (Hundsdorfer \& Verwer } \\
\text { 2003; Cheung et al., 2008) }\end{array}$ & $\begin{aligned} \frac{\partial L a v}{\partial t} & =\frac{\partial}{\partial x}\left(D \frac{\partial L a v}{\partial x}\right)+\frac{\partial}{\partial y}\left(D \frac{\partial L a v}{\partial y}\right)- \\
& -\frac{\partial}{\partial x}(u-L a v)-\frac{\partial}{\partial y}(v-N)-\lambda-L a v\end{aligned}$ & $\begin{array}{l}\mathrm{D}=\text { diffusion parameter } \\
(\mathrm{u}, \mathrm{v})=\text { velocity parameters } \\
\mathrm{LAV}=\text { larvae recruitment }\end{array}$ \\
\hline Adult movement & $\mathrm{Cm} * \mathrm{~h}^{-1}$ & $\begin{array}{l}\mathrm{Cm}=\text { centimetre } \\
\mathrm{h}=\text { hour }\end{array}$ \\
\hline $\begin{array}{l}\text { Natural mortality } \\
\text { (Pauly, 1980; Cheung et } \\
\text { al., 2011) }\end{array}$ & $\begin{array}{l}\mathrm{M}=-0.4851-0.0824 * \log (\text { Winf })+0.6757 \\
* \log (\mathrm{K})+0.4687 * \log (\mathrm{T})\end{array}$ & $\begin{array}{l}\text { Winf = asymptotic weight } \\
\mathrm{K}=\text { von Bertalanffy growth parameter } \\
\mathrm{T}=\text { average water temperature in the } \\
\text { animal's range. }\end{array}$ \\
\hline Fishing mortality at MSY & $\mathrm{F}_{\mathrm{MSY}}=0.4 * \mathrm{M}$ & $\mathrm{M}=$ Natural mortality \\
\hline
\end{tabular}


Table II. Estimation of the average error (0-1 range) and standard deviation by comparing timeseries of survey data with modelled data at cells level (by cell) and by aggregating all the cells for each species with survey data in the NEA (cell sum).

993

\begin{tabular}{llll}
\hline Species & Time-series & GFDL & MEDQ934A \\
\hline Herring & By cell & $0.43 \pm 0.15$ & $0.44 \pm 9957$ \\
& Cell sum & $0.27 \pm 0.17$ & $0.23 \pm 0.16$ \\
\hline Mackerel & By cell & $0.46 \pm 0.15$ & $0.49 \pm 99.16$ \\
& Cell sum & $0.30 \pm 0.29$ & $0.41 \pm 9979$ \\
\hline \multirow{2}{*}{ Sprat } & By cell & $0.49 \pm 0.17$ & $0.47 \pm 098$ \\
& Cell sum & $0.31 \pm 0.29$ & $0.26 \pm 0.22$ \\
\hline
\end{tabular}

1000

1001 Table III. Mean and variance of sea surface temperature (SST) and primary production (PP) 1002 changes by ICES areas. Current temperature and differences between different futures (20201003 2039, 2050-2069, 2080-2099) and present (2000-2019). Temperature is in Celsius degrees and 1004 primary production in percentage change. Northern areas are shadowed. Negative average 1005 primary production is highlighted in bold.

\begin{tabular}{llllllll}
\hline & \multicolumn{3}{l}{$2020-2039$} & $2050-2069$ & \multicolumn{2}{l}{$2080-2099$} \\
\hline Area & Scenario & SST & PP & SST & PP & SST & PP \\
\hline II & RCP2.6 & $+0.3 \pm 0.1$ & $+1.9 \pm 0.4$ & $+0.7 \pm 0.8$ & $+5.0 \pm 5.8$ & $+0.5 \pm 0.8$ & $+1.9 \pm 2.2$ \\
& RCP8.5 & $+0.1 \pm 0.1$ & $+0.0 \pm 1.6$ & $+1.4 \pm 1.1$ & $+9.1 \pm 6.2$ & $+2.6 \pm 2.0$ & $+11 \pm 3.7$ \\
\hline III & RCP2.6 & $+0.9 \pm 0.1$ & $+4.2 \pm 3.3$ & $+0.9 \pm 0.6$ & $+10 \pm 12$ & $+0.8 \pm 0.5$ & $+5.2 \pm 26$ \\
& RCP8.5 & $+0.8 \pm 0.1$ & $+5.2 \pm 6.1$ & $+2.0 \pm 0.7$ & $+13 \pm 21$ & $+3.6 \pm 1.1$ & $+17 \pm 30$ \\
\hline IV & RCP2.6 & $+0.5 \pm 0.7$ & $\mathbf{- 1 0} \pm \mathbf{1 5}$ & $+0.5 \pm 0.3$ & $\mathbf{- 1 2} \pm \mathbf{1 2}$ & $+0.2 \pm 0.3$ & $\mathbf{- 1 4} \pm \mathbf{1 5}$ \\
& RCP8.5 & $+0.5 \pm 0.1$ & $\mathbf{- 6 . 4} \pm \mathbf{9 . 3}$ & $+1.2 \pm 0.5$ & $\mathbf{- 1 1} \pm \mathbf{1 2}$ & $+2.3 \pm 0.9$ & $\mathbf{- 1 4} \pm \mathbf{1 0}$ \\
\hline V & RCP2.6 & $+0.2 \pm 0.0$ & $\mathbf{- 6 . 0} \pm \mathbf{5 . 7}$ & $-0.1 \pm 0.3$ & $\mathbf{- 1 1} \pm \mathbf{1 0}$ & $-0.3 \pm 0.1$ & $\mathbf{- 1 2} \pm \mathbf{1 1}$ \\
& RCP8.5 & $-0.1 \pm 0.5$ & $\mathbf{- 4 . 3} \pm \mathbf{1 . 5}$ & $0.0 \pm 0.1$ & $\mathbf{- 1 5} \pm \mathbf{1 7}$ & $+0.6 \pm 0.8$ & $\mathbf{- 1 7} \pm \mathbf{1 6}$ \\
\hline VI & RCP2.6 & $+0.2 \pm 0.1$ & $\mathbf{- 1 1} \pm \mathbf{1 2}$ & $+0.2 \pm 0.1$ & $\mathbf{- 1 9} \pm \mathbf{2 4}$ & $0.0 \pm 0.1$ & $\mathbf{- 2 1} \pm \mathbf{2 6}$ \\
& RCP8.5 & $+0.2 \pm 0.2$ & $\mathbf{- 8 . 3} \pm \mathbf{9 . 2}$ & $+0.3 \pm 0.1$ & $\mathbf{- 2 3} \pm \mathbf{3 0}$ & $+0.4 \pm 0.5$ & $\mathbf{- 3 2} \pm \mathbf{2 8}$ \\
\hline VII & RCP2.6 & $+0.3 \pm 0.2$ & $\mathbf{- 1 2} \pm \mathbf{1 3}$ & $+0.3 \pm 0.2$ & $\mathbf{- 1 7} \pm \mathbf{2 3}$ & $+0.3 \pm 0.2$ & $\mathbf{- 1 9} \pm \mathbf{2 6}$ \\
& RCP8.5 & $+0.4 \pm 0.2$ & $\mathbf{- 8 . 4} \pm \mathbf{1 0}$ & $+1.0 \pm 0.8$ & $\mathbf{- 2 1} \pm \mathbf{2 6}$ & $+2.0 \pm 1.6$ & $\mathbf{- 2 7} \pm \mathbf{2 6}$ \\
\hline
\end{tabular}




\section{Figures}

1009 Figure 1. The proportion of catches of the four main pelagic species (BWH blue whiting, HER 1010 herring, MAC mackerel, SPR sprat) considered per ICES area in relation to total catches for 1011 the NEA. It is based on Official Nominal Catches 2006-2013 from ICES database which 1012 includes fish, shellfish and algae catch. Country abbreviations are; Denmark (DK), Faeroe 1013 Islands (FO), Finland (FI), Iceland (IS), Ireland (IE), Netherlands (NL), Norway (NO), Poland 1014 (PL), Russian Federation (RU), Scotland (UKM), Sweden (SE) and United Kingdom (UK).

1015

1016

1017

Figure 2. Time series of projections of 3 pelagic species with the two different biogeochemical 1018 1019 model forcing in the same cells where there is survey data. The abundance time-series are normalized and the values have been smoothed using a 5-year moving average.

1020

1021

1022

Figure 3. Relative change of potential MSY catches for the four pelagic species in ICES areas

II to VII, relative to 2015 catches. RCP2.6 (green) and RCP8.5 (blue) represent a low and high 1024 future greenhouse emission scenario, respectively. Both biogeochemical models (GFDL and 1025 1026 NEMO-MEDUSA) were used to drive two fisheries projections for each scenario. Then, the mean value is used to calculate the straight-line trend and the shaded ranges show the difference 1027 between both projections.

Figure 4. Left panel, model projections of current species distribution (20 years average from 1031 2000 to 2019). Right panel, projected relative changes of potential catches (average of two biochemical models) under the high emission scenario (RCP8.5) in ICES areas II to VII. The columns represent differences between different futures (2020-2039, 2050-2069, 2080-2099) and the present (2000-2019). 
Fig. 1

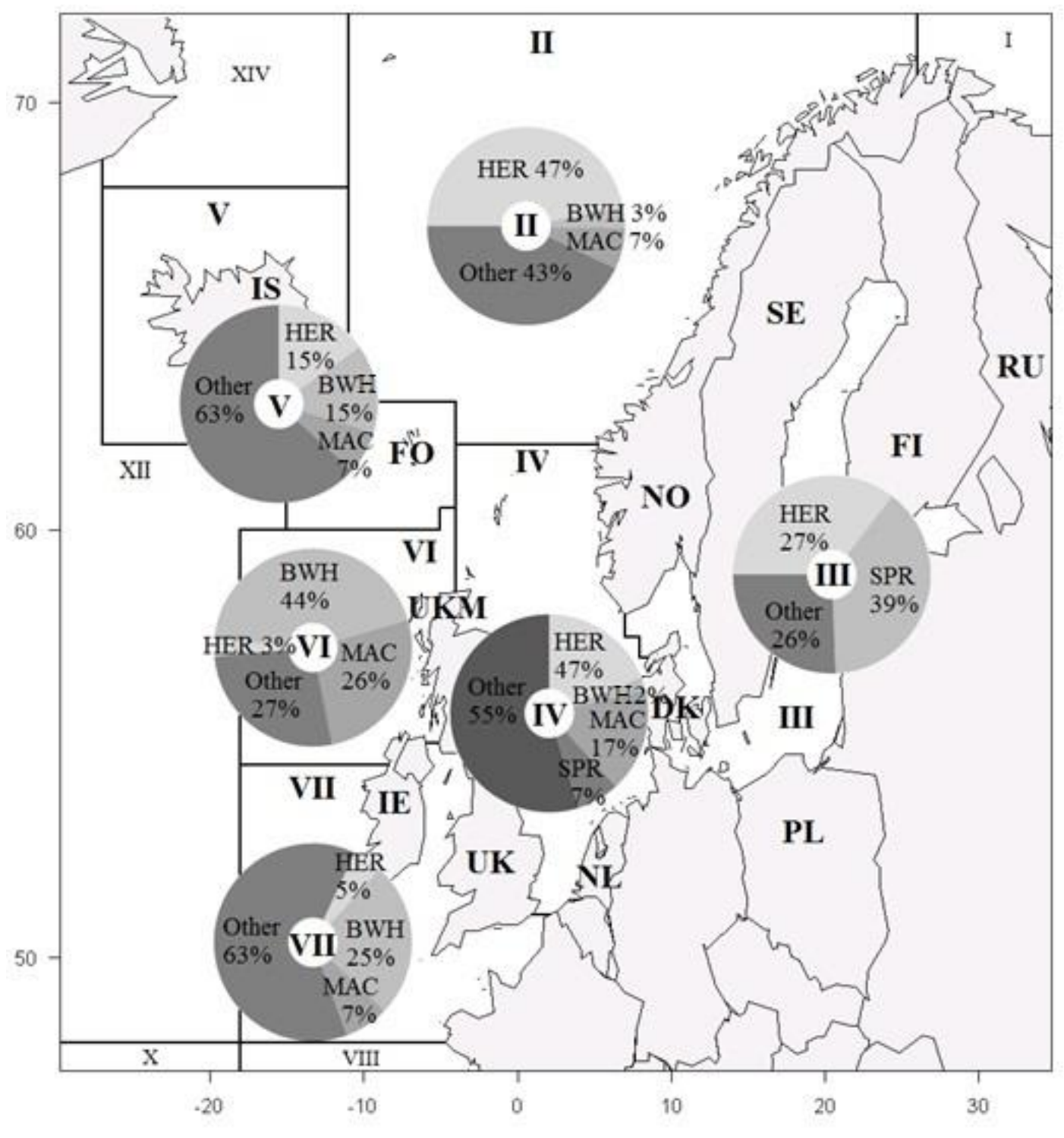


Fig. 2

\section{Herring}

a)

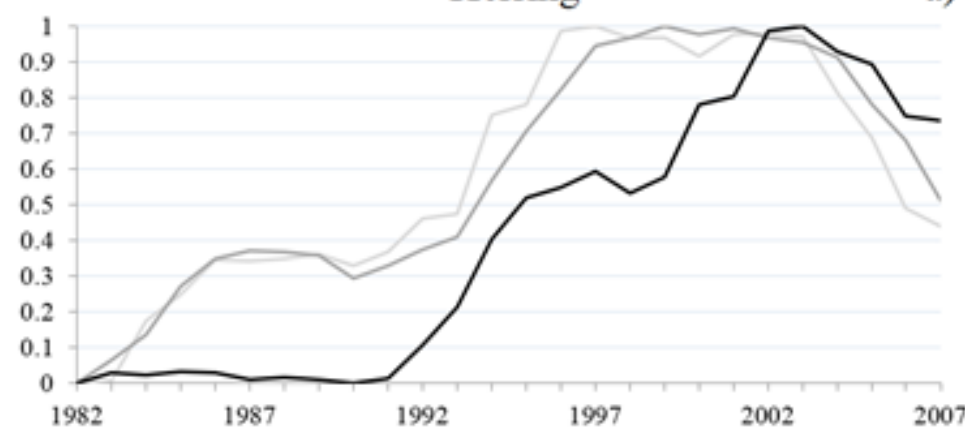

Mackerel

b)
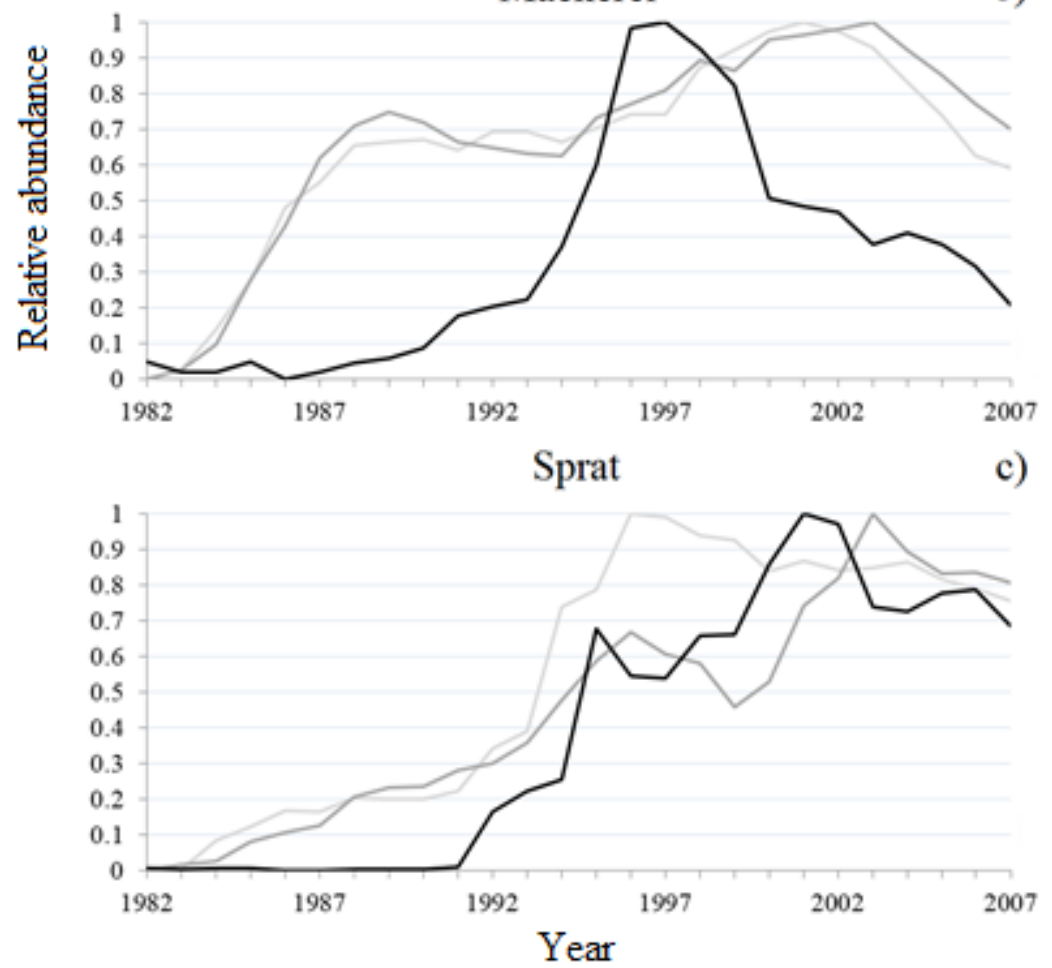

1039

GFDLesm2mRCP IPCC5 - Medusa_IPCC5 - Surveys 
Fig. 3

1042
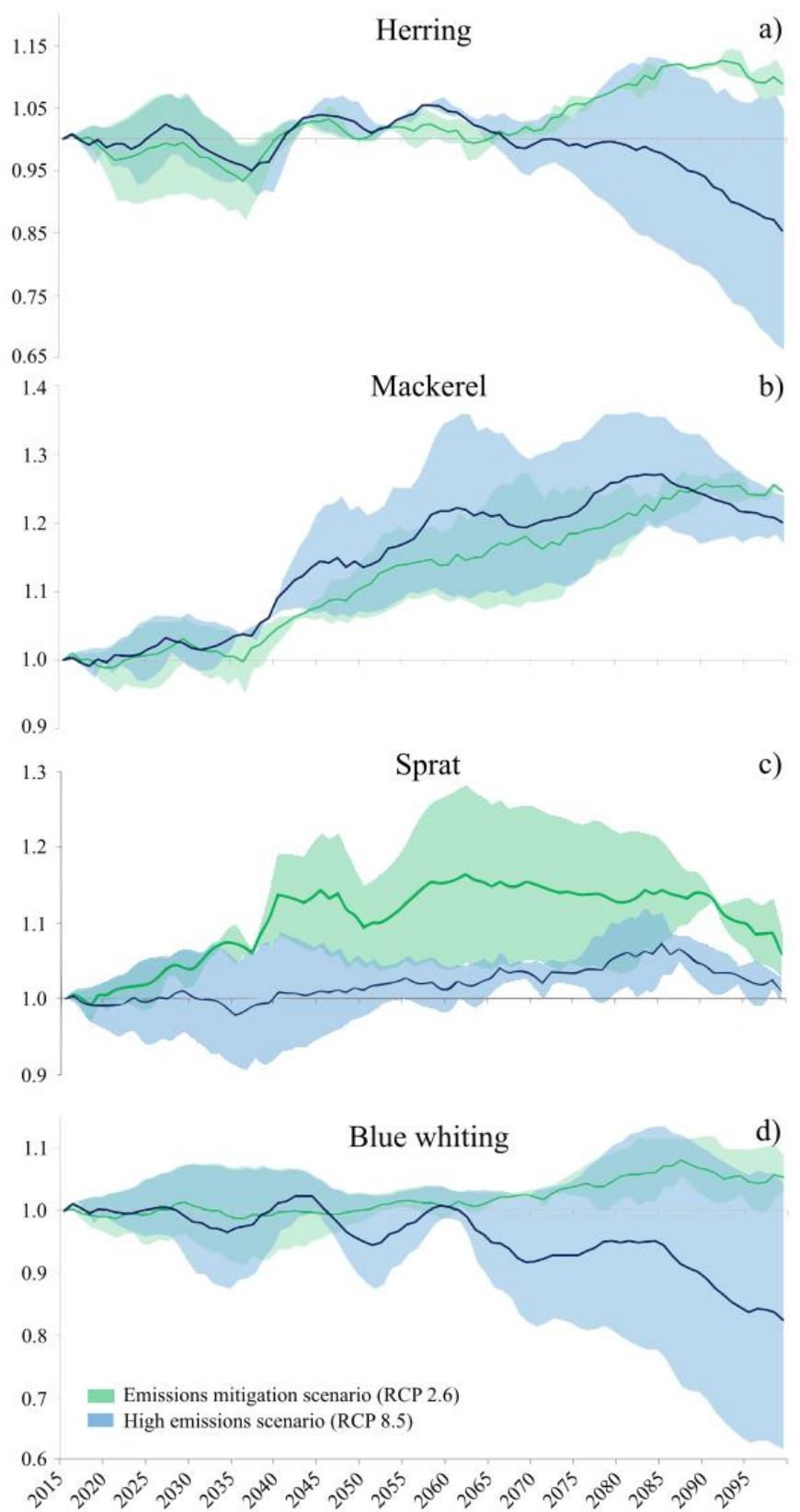
Fig. 4-

Relative distribution Relative change
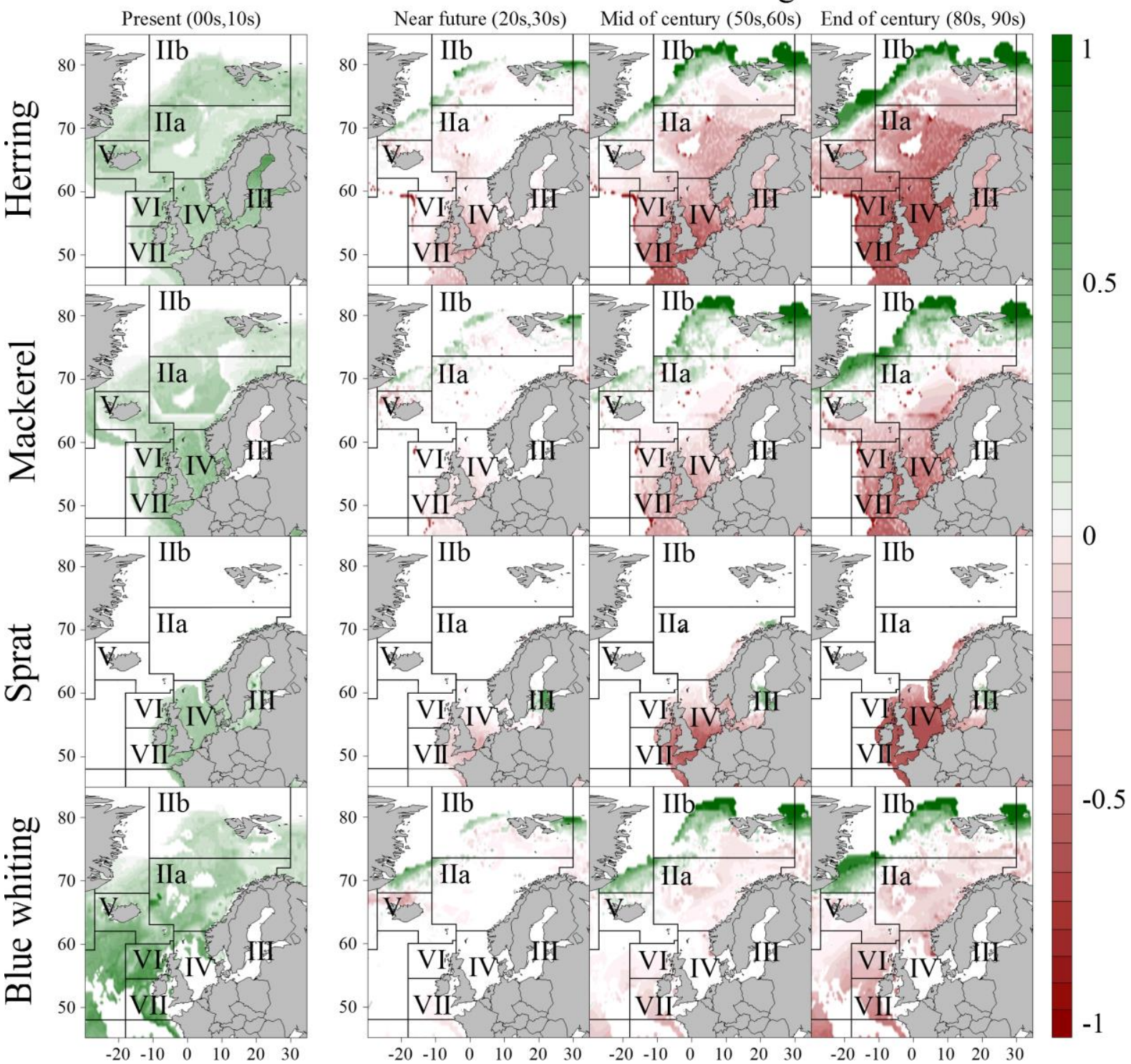